\title{
FERC's Expansive Authority to Transform the Electric Grid
}

\begin{abstract}
Joel B. Eisen*
Using an unprecedented historical analysis of over 100 years of law dating to the Progressive Era, this Article concludes that the Supreme Court's landmark decision in Federal Energy Regulatory Commission ("FERC") v. Electric Power Supply Association properly asserted that FERC has ample authority to pursue broad environmental and energy goals in transforming the electric grid. Building on the Court's finding that FERC may regulate "practices" that "directly affect" rates in wholesale electricity markets, the analysis develops a detailed standard that is consistent with interpretation of regulatory statutes in each of three distinct eras: the Progressive Era, the era of regulation of utilities under firm-specific tariffs, and the modern, market-based era. This Article also sets forth and discusses in depth four guiding principles that specify how FERC may use the "directly affecting" standard to take sweeping measures to inject new values in the wholesale electricity markets, such as accounting for environmental externalities. Analyzing FERC's initiatives to promote demand response (techniques for reducing electricity consumption, upheld in FERC $v$. EPSA) and a hypothetical carbon price imposed on bids in wholesale markets, the Article broadens our understanding of what FERC can regulate and what states can regulate, aiming to lessen ongoing jurisdictional tension and provide a means for addressing difficult cases involving preemption of state laws. The hope is
\end{abstract}

* Copyright (c) 2016 Joel B. Eisen. Professor of Law, University of Richmond School of Law. The author thanks Emily Hammond, Dick Pierce, Jim Rossi, Joe Tomain, William Boyd, and the participants in conferences on electric utility regulation at Northwestern University Law School and the University of Texas, FPA workshops in Washington, D.C., and participants in the PUC Clean Energy Collaborative workshop in Washington, D.C. and a Richmond Law faculty workshop who commented on earlier drafts. The author also thanks Andy Flavin, Mercer May, and Ryan Suit for outstanding research assistance, and Joel Bernstein of Somos, Inc. for insights about the telecommunications industry. 
that additional clarity about jurisdictional boundaries will allow for more valuable innovation and experimentation in refashioning the electric grid.

\section{TABLE OF CONTENTS}

INTRODUCTION 1785

I. THE CORE OF A RESILIENT APPROACH TO THE FPA 1790

II. THE FOUNDATION OF MODERN AUTHORITY: "UNDUE DISCRIMINATION" AND "PRACTICES AFFECTING RATES" FROM THE RAILROAD ERA TO THE DAWN OF ELECTRIC INDUSTRY COMPETITION 1797

A. Addressing Discriminatory Practices in Progressive Era

Railroad Regulation

1. Remedying Discrimination: The Hepburn Act ........ 1799

2. Judicial Construction in the Pre-New Deal Era ....... 1802

B. "Discrimination" and "Practices Affecting Rates" from the FPA's Enactment Through the Rise of Competition and Modern Markets 1806

1. Agency and Judicial Construction of "Undue Discrimination" After the FPA's Enactment ............ 1807

2. Post-FPA Changes in "Practices Affecting Rates".... 1809

III. THE TRANSITION TO COMPETITION AND MODERN

APPLICATIONS OF "UNDUE DISCRIMINATION" AND "PRACTICES AFFECTING RATES".

A. Evolution of "Undue Discrimination" to an IndustryWide Focus.

B. Evolution of "Practices Affecting Rates" in the Modern Era.

1. FERC Interprets "Practices" for Section 205 Filings: The Prior Notice Order....

2. Toward a New Meaning of "Practices" and a Limiting Principle.

C. D.C. Circuit Cases Supporting and Limiting Authority over Practices Affecting Rates

1. Capacity Market Cases

2. Transmission Planning and Cost Allocation: South Carolina Public Service Authority....

3. A Limiting Principle for "Practices Affecting Rates": Practices that Directly Relate to or Are Integral to the Proper Functioning of the Wholesale Markets.. 1829

IV. APPLiCATIONS AND IMPLiCATIONS OF APPlying THE 
A. Four Factors for More Clearly Fixing the Limits of FERC's Authority

1. FERC Is Regulating Wholesale Market Participants in Their Trading Activities

2. FERC Is Addressing System Adequacy by Regulating the Quantity of Inputs to the Markets ... 1838

3. FERC Is Regulating Market-Wide Features to Remedy Discrimination Against One Resource in Favor of Another .... 1840

4. FERC's Oversight Aims at Conduct that Directly and Significantly Affects Wholesale Rates

B. Addressing Potential Preemption of State Laws

CONCLUSION 1848

\section{INTRODUCTION}

Some want the Federal Energy Regulatory Commission ("FERC") to act boldly in transforming the electric grid. ${ }^{1}$ Others believe it has overreached its authority when it has acted to promote reduced electricity consumption, stimulate innovation, and address climate change. ${ }^{2}$ This conflict came to a head in FERC v. Electric Power Supply Association ("FERC v. EPSA"), ${ }^{3}$ involving FERC's Order 745.4

1 See, e.g., William Boyd, Public Utility and the Low-Carbon Future, 61 UCLA L. Rev. 1614, 1666-74 (2014); Joel B. Eisen, An Open Access Distribution Tariff: Removing Barriers to Innovation on the Smart Grid, 61 UCLA L. REV. 1712 (2014) [hereinafter An Open Access Distribution Tariff] (arguing for FERC to promulgate an "open access distribution tariff" to promote grid innovation); Steven Weissman \& Romany Webb, Addressing Climate Change Without Legislation, Volume 2: FERC: How the Federal Energy Regulatory Commission Can Use Its Existing Legal Authority to Reduce Greenhouse Gas Emissions and Increase Clean Energy Use, Berkeley ENERgy \& Climate INITIATIVE (2014), available at www.law.berkeley.edu/files/ccelp/FERC_Report_ FINAL.pdf (discussing FERC jurisdiction and numerous policy proposals).

2 See, e.g., Sharon B. Jacobs, Bypassing Federalism and the Administrative Law of Negawatts, 100 IowA L. REV. 885 (2015) (criticizing Order 745 as overreaching).

3 FERC v. Elec. Power Supply Ass'n, 136 S. Ct. 760 (2016). See generally Joel B. Eisen, Who Regulates the Smart Grid?: FERC's Authority over Demand Response Compensation in Wholesale Electricity Markets, 4 SAN DiEgo J. ClimATE \& ENERGY L. 69 (2013) [hereinafter Who Regulates the Smart Grid?] (analyzing jurisdictional issues associated with demand response).

4 Demand Response Compensation in Organized Wholesale Energy Markets, Order No. 745, 134 FERC II 61,187 (Mar. 15, 2011); Eisen, Who Regulates the Smart Grid?, supra note 3, at 72 (discussing Order 745). See generally Richard J. Pierce Jr., A Primer on Demand Response and a Critique of FERC Order 745, 102 GEO. WASH. U. J. ENERGY \& ENVTL. L. 102 (2011) [hereinafter Demand Response] (suggesting that a reviewing court should uphold Order 745). 
Reversing a D.C. Circuit decision, the Supreme Court held that FERC has authority over "demand response" (techniques by which end-use customers directly reduce consumption of electricity) in wholesale electricity markets. ${ }^{5}$ The Court also held that FERC's formula for pricing demand response at the market price - the same price paid to generators - was not arbitrary and capricious. ${ }^{6}$ Using a historical analysis of modern cases and durable principles dating to the Progressive Era, ${ }^{7}$ this Article concludes that the Court was correct in asserting that FERC has ample authority for Order 745, and also explains that FERC can take sweeping measures such as a "carbon adder" that would aim at the most pressing energy and environmental issues of our time.

The Federal Power Act ("FPA") is largely intact since its 1935 enactment and did not contemplate today's wholesale markets and other advances. ${ }^{8}$ FERC therefore justifies its initiatives under its existing authorities to prevent "undue discrimination" by regulated entities in their "practices" affecting wholesale electricity rates (for convenience, this Article refers to the latter as the "practices affecting rates" clause). ${ }^{9}$ FERC's critics claimed these provisions could not be stretched to justify Order 745.10 They argued that the FPA cannot be interpreted broadly to allow it to pursue goals other than achieving just and reasonable electricity rates, and that doing so for unauthorized purposes infringes on states' regulatory authority. ${ }^{11}$ In

5 Elec. Power Supply Ass'n, 136 S. Ct. at 767.

6 Id.

7 See infra Part II.

8 See James J. Hoecker \& Douglas W. Smith, Regulatory Federalism and Development of Electric Transmission: A Brewing Storm?, 35 ENERGY L.J. 71, 73 (2014); Jacobs, supra note 2, at 941. With respect to the wholesale markets specifically, see Emily Hammond \& David B. Spence, The Regulatory Contract in the Marketplace, 69 VAND. L. REV. 141, 198 (2016) (noting that the wholesale markets were a "stark departure from historical practice" and not contemplated in 1935).

9 See infra Part III (discussing these aspects of the FPA).

10 See generally Jacobs, supra note 2.

11 These mirror the ongoing arguments against the use of broad agency discretion under other statutes, such as the Environmental Protection Agency's climate change rules. See, e.g., Util. Air Regulatory Grp. v. EPA (UARG), 134 S. Ct. 2427 (2014) (overturning portions of EPA rules addressing greenhouse gas emissions); Amanda C. Leiter, Utility Air Regulatory Group v. EPA: A Shot Across the Bow of the Administrative State, 10 DUKE J. CONST. L. \& PUB. POL'y 59, 60 (2015) (discussing UARG and claiming that it "creates a presumption against reading ambiguous statutory text to grant agencies authority that is either 'too expansive' or 'too expensive."'). Other recent challenges to EPA's interpretations of the Clean Air Act include EPA v. EME Homer Generation, L.P., 134 S. Ct. 1584 (2014) (states challenged EPA's rule regulating interstate pollution 
FERC v. EPSA, the Court soundly rejected these and other arguments against Order 745.12

The aim of this Article is to demonstrate that the Supreme Court accurately characterized FERC's jurisdiction, and to explain the extent of FERC's authority under FERC v. EPSA. To that end, the Article uses a historical approach that examines the evolution of the law over the past 100 years in three distinct eras: railroad regulation of the early 1900s, where the "practices affecting rates" language originated; regulation of the electric utility industry under the FPA from 1935 through the industry transition to competition beginning in the 1980s; and regulation in the modern market era. No analysis to date has taken such a comprehensive approach to understanding FERC's authority, nor aimed to reconcile all of this law. This Article fills this gap by providing four guiding principles to enable courts and policymakers to apply the "directly affecting" standard in individual situations involving FERC's jurisdiction. Over time, the interpretation of "practices affecting rates" has traced a distinctive arc, featuring flexibility about conduct being regulated. Originally, agencies used it to remedy individual firms' discriminatory activities — for example, railroads' secret preferences. ${ }^{13}$ Following the FPA's enactment, the focal point for defining "practices" shifted to determining how comprehensively rate-setting tariffs should describe utility operations. ${ }^{14}$ Today, as the Court has acknowledged, "practices affecting rates" means the terms, conditions, and rules that govern wholesale markets. ${ }^{15}$ FERC's role has shifted from overseeing whether an individual utility harmed customers, to whether market operations do. Under FERC $v$. EPSA, this extends FERC's reach to a wide range of entities whose conduct affects wholesale rates directly and significantly.

This Article discusses how FERC v. EPSA's "directly affecting" language empowers FERC to regulate those practices that affect wholesale markets directly and significantly, or are integral to the markets' proper functioning. It adds four factors to the Court's analysis for courts and policymakers to consider in applying this standard. This recognizes that FERC's expansive "practices affecting rates" authority is well grounded in 100 years of history. While the

\footnotetext{
transport), and White Stallion Energy Ctr., LLC v. EPA, 748 F.3d 1222 (D.C. Cir. 2014) (states challenged EPA's approach to regulating mercury emissions).

12 FERC v. Elec. Power Supply Ass'n, 136 S. Ct. 760, 775-82 (2016).

13 See infra Part II.A (discussing this body of law).

14 See infra Part II.B (discussing the interpretation of the FPA during this period).

15 See infra Part III (discussing the modern view of FPA provisions).
} 
"practices" being regulated have changed, the prevailing trend over the years has been regulatory growth and breadth, not shortcomings and limits. FERC $v$. EPSA highlights a resilient statute: the FPA's terms are not frozen in amber, as the statute has adapted to changing market realities. Therefore, the Court has properly confirmed that the FPA has flexibility to address modern developments in the electric grid.

As a prudential matter, FERC might not advocate certain policies to transform the electric grid; backlash to some of its reform initiatives has been severe, prompting agency retrenchment and reticence. ${ }^{16}$ FERC v. EPSA's upholding of Order 745 shows that FERC can boldly pursue policy goals (such as promoting reduced electricity consumption) going beyond the pursuit of economic efficiency in wholesale markets. It can even take an "environmental" action - such as addressing climate change through a carbon $\operatorname{adder}^{17}$ — if it has a direct relationship to wholesale rates. Moreover, it does not matter that its initiatives might impinge on state authority. The Supreme Court has long settled that FERC can act if it does not engage in direct regulation of matters expressly reserved to the states. ${ }^{18}$ FERC $v$. EPSA reiterated this central principle and held that it did not invalidate Order 745.19

This confirmation of FERC's broad authority brings clarity to energy law federalism. The balance of power between the states and FERC has been the subject of considerable recent uncertainty. The FPA defines jurisdiction in terms of separate and exclusive "retail" and "wholesale" spheres, with a complex matrix of actions regulated either by FERC or

16 See, e.g., David E. McNabb, Public Utilities: Management Challenges for the 21st CENTURY 230-31 (2005) (discussing the political opposition to the Standard Market Design proposal); John S. Moot, Subsidies, Climate Change, Electric Markets and the FERC, 35 ENERGY L.J. 345, 347 (2014); Gerald Norlander, May the FERC Rely On Markets to Set Electric Rates?, 24 ENERGY L.J. 65, 65-66 (2003) (discussing the SMD's features).

17 For a discussion of the features of a carbon adder, see Weissman \& Webb, supra note 1 , at 4 .

18 See infra Part III.C (discussing cases reaching this conclusion).

19 FERC v. Elec. Power Supply Ass'n, 136 S. Ct. 760, 776 (2016):

FERC regulation does not run afoul of $\S 824(\mathrm{~b})$ 's proscription just because it affects - even substantially — the quantity or terms of retail sales. It is a fact of economic life that the wholesale and retail markets in electricity, as in every other known product, are not hermetically sealed from each other. To the contrary, transactions that occur on the wholesale market have natural consequences at the retail level. And so too, of necessity, will FERC's regulation of those wholesale matters. 
by the states. ${ }^{20}$ In today's electric power system, electric current flows across state lines. ${ }^{21}$ Inevitably, then, jurisdictional tensions have arisen - even though FERC and the states nominally remain within their "assigned spheres." 22 This leads some to deem the situation intractable, calling the FPA's language drawing sharp jurisdictional boundaries outmoded. 23

As the Court has determined, the "practices affecting rates" language can alleviate this tension. This conclusion follows from a long line of judicial decisions on "practices" predating FERC v. EPSA that yield detailed limits on what FERC and the states can regulate, giving a rich context to the distinction between "retail" and "wholesale." The approach outlined in this Article can go a long way toward deciding which responsibilities are best assumed by each level of government, or by both concurrently. This can be accomplished by applying its limiting principles in a manner that gives sufficient guidance to federal and state regulators, utilities, and consumers.

Part I examines the FPA's structure and text, the rise of the wholesale electricity markets, and the jurisdictional challenges, using the example of demand response. Part II discusses the Progressive Era origins of "undue discrimination" and "practices affecting rates" and their interpretation before the emergence of the modern wholesale markets. Part III discusses the modern era and the foundation for interpreting "practices affecting rates" and discrimination comparably, arguing for and describing the standard that allows FERC to govern practices directly and significantly affecting wholesale market rates. To provide guidance to courts and policymakers for handling contentious cases, Part IV articulates four factors for elaborating on the standard, and also suggests how to apply the standard in challenging situations when preemption questions arise.

20 Charts detailing federal, state, and concurrent jurisdiction under the FPA illustrate this complexity. See Scott Hempling, Electricity Jurisdiction: Actions by Market Participants, SCOTT HeMPLING L., http://www.scotthemplinglaw.com/files/ attachments/elec_jurisdiction_hempling_020514.pdf (last visited Jan. 22, 2016).

21 This interconnectedness subjects most electricity transmission to federal regulation under the FPA. 16 U.S.C. § 824(b) (2012) (claiming federal jurisdiction over "transmission of electric energy in interstate commerce"); FPC v. Fla. Power \& Light Co., 404 U.S. 453, 454 (1972) (confirming federal jurisdiction on this basis).

22 See Nw. Cent. Pipeline Corp. v. State Corp. Comm'n of Kan., 489 U.S. 493, 515 n.12 (1989).

23 Jacobs, supra note 2, at 940-41 (stating that, "the federalism boundaries drawn in 1935 in the FPA may no longer be appropriate in today's world"). 


\section{THE CORE OF A RESILIENT APPROACH TO THE FPA}

Before FERC $v$. EPSA, talk of the FPA's resilience and adaptability seemed inapt, considering its core provisions have not changed substantially in eighty years. The FPA's division of authority between FERC and the states has received the sharpest criticism. The FPA closed the "Attleboro gap" and addressed the inability of state public utility commissions ("PUCs") to regulate large interstate holding companies, ${ }^{24}$ giving the Federal Power Commission ("FPC"), FERC's predecessor, authority over "all wholesale sales in interstate commerce." 25 It divides authority rigidly between FERC and the states — FERC regulates at "wholesale" and the states at "retail." 26 The core jurisdictional provision, section 201, extends federal jurisdiction to "public utilities" 27 engaged in "the transmission of electric energy in interstate commerce and to the sale of electric energy at wholesale in interstate commerce."28 FERC has exclusive jurisdiction over

24 The 1927 Supreme Court decision in Pub. Util. Comm'n of R.I. v. Attleboro Steam E Elec. Co., 273 U.S. 83, 89-90 (1927), recognized constitutional limits on states regulating interstate energy transactions. The Court concluded that neither Massachusetts nor Rhode Island had the power to regulate an interstate transaction, and "if such regulation is required it can only be attained by the exercise of the power vested in Congress." Id. at 90; see also New York v. FERC, 535 U.S. 1, 6 (2002) ("When it enacted the FPA in 1935, Congress authorized federal regulation of electricity in areas beyond the reach of state power, such as the gap identified in Attleboro, [and] it also extended federal coverage to some areas that previously had been state regulated."); Boyd, supra note 1, at 1629-30 (noting that, "[w] hile . . holding companies emerged in part to facilitate the building of regional systems, they also provided a means of escaping rate regulation by states and thus became an object of intense regulatory scrutiny and concern during the Great Depression as utilities went bankrupt across the country. In 1935, Congress enacted two statutes to deal with the increasingly interstate nature of the electricity industry and the abuses of the holding companies").

25 Fed. Power Comm'n v. S. Cal. Edison Co., 376 U.S. 205, 216 (1964).

26 Joel B. Eisen, Regulatory Linearity, Commerce Clause Brinksmanship, and Retrenchment in Electric Utility Deregulation, 40 WAKE FOREST L. REV. 545, 549 (2005) [hereinafter Regulatory Linearity].

27 The Federal Power Act's definition of a "public utility" is not the same as the common understanding of a "utility." The Act defines a "public utility" as "any person who owns or operates facilities subject to the jurisdiction of the Commission," that is, "any person who owns or operates" facilities for the transmission of electric energy in interstate commerce and to the sale of electric energy at wholesale in interstate commerce. 16 U.S.C. \& 824(e) (2012).

28 The FPA granted the Federal Power Commission ("FPC"), now FERC, authority over the rates and conditions for the interstate sale and transmission of electricity at wholesale (sales before resale to eventual consumers). 16 U.S.C. § 824(b) (claiming federal jurisdiction over "transmission of electric energy in interstate commerce"); FPC v. Fla. Power \& Light Co., 404 U.S. 453, 461-63 (1972) (affirming 
wholesale sales of electricity and transmission in interstate commerce; states have jurisdiction over retail sales. ${ }^{29}$

Professor Hannah Wiseman calls this bright line "antiquated,"30 arbitrary and unworkable in today's interconnected, interstate electric grid. ${ }^{31}$ Compared to the more dynamic relationship between the states and the federal government prevalent under other modern regulatory statutes, ${ }^{32}$ assigning separate and exclusive regulatory spheres to FERC and the states appears to reflect "stagnant vestiges" of the long discarded approach of "dual federalism." 33 Calls for new approaches to energy law federalism abound. ${ }^{34}$

That is one story, but there is another that resonates in FERC $v$. EPSA: a story of statutory resilience and flexibility that addresses and settles many core questions. The foundation of this approach is that interpretations of the FPA's two central regulatory provisions have shifted steadily over time to accommodate new developments in the electric utility industry, and to empower FERC to regulate them. These two provisions are FPA sections 205 and 206. Section 205 mandates that all wholesale rates must be just and reasonable, ${ }^{35}$ and prohibits utilities from granting any "undue prejudice or disadvantage." Section 206 announces that if "any rule, regulation, practice, or contract affecting such rate, charge, or classification is

FPC jurisdiction on this basis).

29 FERC's authority is plenary, and extends to all sales in interstate commerce except those explicitly made subject to regulation by the states. See Gulf States Util. Co. v. Fed. Power Comm'n, 411 U.S. 747, 758 (1973).

30 Hannah J. Wiseman, Moving Past Dual Federalism to Advance Electric Grid Neutrality, 100 IOWA L. REV. Bull. 97, 99 (2015).

31 Id. at 97 (noting that, "[e]lectricity has changed in so many ways since the passage of the Federal Power Act ("FPA") - a 1935 statute that allocated jurisdiction over electricity between states and the federal government - that the Act's division of state and federal authority is increasingly irrelevant and artificial").

32 For example, there is a rich body of scholarship on the "cooperative federalism" approach to environmental law, which implements an interactive relationship between the U.S. Environmental Protection Agency and the states. See, e.g., Ann E. Carlson, Iterative Federalism and Climate Change, 103 Nw. U. L. REv. 1097 (2009) (discussing the origins of environmental federalism and the contemporary approach); Emily Hammond \& David L. Markell, Administrative Proxies for Judicial Review: Building Legitimacy from the Inside-Out, 37 HARV. ENVTL. L. REV. 313 (2013).

33 Wiseman, supra note 30, at 97.

34 See, e.g., Hari M. Osofsky \& Hannah J. Wiseman, Dynamic Energy Federalism, 72 MD. L. REV. 773 (2013) (proposing a "novel" approach to the subject).

3516 U.S.C. $\S 824 d$ (2012). All rates charged by any public utility "in connection with the ... sale of electric energy subject to the jurisdiction of the Commission, and all rules and regulations affecting or pertaining to such rates or charges" are required to be "just and reasonable." Id. 
unjust, unreasonable, unduly discriminatory or preferential," FERC must "determine the just and reasonable rate, charge, classification, rule, regulation, practice, or contract to be thereafter observed and in force, and shall fix the same by order." 36

The flexible approach to the FPA has several fundamental attributes. The touchstone for regulatory intervention is remedying anticompetitive "discrimination," the umbrella term for activities harming customers of regulated firms. Since the 1900s, regulators have consistently viewed discrimination in context, focusing on whether firms' conduct - "practices" — harms customers, rather than enumerating specific prohibited practices. The nature of these "practices" has changed over time. Agencies have interpreted regulated "practices" broadly, but with some limits, the most significant being a direct and significant relationship to the rates for service subject to agency control.

As the electric utility industry has transformed, FERC's regulatory approach has as well. In the past several decades, wholesale markets for electricity have grown and substantially displaced price regulation of individual firms. ${ }^{37}$ This transformation began in the 1980s with the rise of independent power generators and competition to entrenched utilities. ${ }^{38}$ It accelerated when FERC issued major orders, Orders $888,39889,{ }^{40}$ and $2000,{ }^{41}$ aimed at preventing transmission line owners from using their monopoly power to prevent others from using the lines. ${ }^{42}$ Regional grid operators known as "independent system

36 Id. $\S 824 \mathrm{e}(\mathrm{a})$. Similar language in section 1(b) of the Natural Gas Act ("NGA") also authorizes FERC jurisdiction to ensure that "practices ... affecting rates" are just and reasonable, and the statutes and decisions under them are read in pari materia. Nw. Cent. Pipeline Corp. v. State Corp. Comm'n of Kan., 489 U.S. 493, 506 (1989) (citing 15 U.S.C. $\& 717 \mathrm{c}, 717 \mathrm{~d}$ ).

37 See generally Hammond \& Spence, supra note 8.

38 Eisen, Regulatory Linearity, supra note 26, at 549-50 (discussing the impact of Public Utility Regulatory Policies Act ("PURPA") on stimulating the growth of competition to established generators and noting that it "essentially invented a market for generation where none previously existed").

39 Promoting Wholesale Competition Through Open Access Non-Discriminatory Transmission Services by Public Utilities; Recovery of Stranded Costs by Public Utilities and Transmitting Utilities, Order No. 888, 18 C.F.R. pts. 35, 385 (1996).

40 Open-Access Same-Time Information System (Formerly Real-Time Information Networks) and Standards of Conduct, Order No. 889, 18 C.F.R. pt. 37 (1996).

41 Regional Transmission Organizations, Order No. 2000, 18 C.F.R. pt. 35 (2000).

42 Order 888 operated on a principle of comparability: the belief that owners of the transmission grid should offer third parties access to the grid on the same or comparable terms and conditions as the transmission owner's own use of the system. See Eisen, Regulatory Linearity, supra note 26, at 550-51; infra Part III.B. 
operators" ("ISOs") and "regional transmission organizations" ("RTOs")43 now administer several different types of wholesale markets for electricity, ${ }^{44}$ under FERC oversight, and seven ISO/RTOs ${ }^{45}$ now serve over one-half of the nation and provide two-thirds of the nation's electricity. ${ }^{46}$ This is far different from the system that prevailed for decades after the FPA's enactment. Then, vertically integrated investor-owned utilities dominated the industry, providing monopoly service to their customers by generating, transmitting and supplying power to their customers, with little need for wholesale power transactions. ${ }^{47}$

In the market-based system, the lens through which FERC views its oversight role has broadened to an industry-wide focus. As it did for "undue discrimination," the Court has now confirmed that FERC can control "practices" on an industry-wide basis, with appropriate limits.

43 Order 888 encouraged (but did not require) the formation of regional Independent System Operators ("ISOs") to help manage the provision of transmission services and oversee wholesale power markets. 18 C.F.R. pts. 35, 385 (establishing requirements for ISOs). Order 2000 continued this transformation by encouraging RTOs' formation and setting forth specific requirements for an entity to qualify as an RTO. 18 C.F.R. pt. 35; Eisen, Regulatory Linearity, supra note 26, at 551-52.

44 ISO/RTOs manage energy, capacity, and ancillary services markets. Energy markets are designed to ensure that enough generation plants are online and able to produce electricity on a day-ahead to one-hour-ahead basis. JAQUELIN COCHRAN ET AL., Nat'l Renewable Energy Lab., Market Evolution: Wholesale Electricity Market Design fOr 21st Century POWer Systems, at vi-vii (2013), available at http://www. nrel.gov/docs/fyl4osti/57477.pdf. Ancillary services markets allow the ISO/RTO to maintain a portfolio of backup generation in case of unexpectedly high demand or if contingencies arise. Joel B. Eisen, Distributed Energy Resources, "Virtual Power Plants," and the Smart Grid, 7 Hous. Envtl. \& Energy L. \& POL'Y J. 191, 203 (2012) (discussing "regulation" and the potential for demand response to participate in ancillary services markets). Forward capacity markets aim for resource "adequacy": to ensure that there is sufficient generating capacity over the long term to meet projected demand, by providing financial incentives for suppliers to keep generating plants online and to induce new investment in generation. COCHRAN ET AL., supra, at vi.

45 The difference between RTO and ISO is today largely semantic, and this Article will use the term "ISO/RTO" to encompass the two. See generally Charles H. Koch, Jr., Collaborative Governance in the Restructured Electricity Industry, 40 WAKE FOREST L. REV. 589 (2005) (discussing comparable ISO and RTO governance models).

46 See Eisen, Regulatory Linearity, supra note 26, at 551; Electric Power Markets: National Overview, FED. ENERGY REG. COMMISSION, http://www.ferc.gov/marketoversight/mkt-electric/overview.asp (last updated Dec. 21, 2015); The Role of ISOs and RTOs, ISO/RTO COUNCIL, http://www.isorto.org/about/Role (last visited Jan. 24, 2016).

47 See Eisen, Regulatory Linearity, supra note 26, at 549-50 (noting the lack of a wholesale market before the 1990s); Hammond \& Spence, supra note 8, at 150; Hoecker \& Smith, supra note 8, at 75 . 
Yet as FERC v. EPSA observed, 48 "practices" has a broad meaning: a practice is "how a company does business," a "method, procedure, process, or rule employed or followed by a company in the pursuit of its objectives." 49 Electricity is a universal commodity, and nearly every business "practice" has a connection to it. Building a shoe manufacturing plant in Massachusetts affects how much electricity is needed on the New England electric grid, but it would be serious overreaching for FERC to assert responsibility for issuing the plant's building permit. "Practices" can undoubtedly have many meanings, and FERC cannot use its breadth to regulate activities unconnected to the markets.

Fortunately, limits on FERC's authority over "practices affecting rates" have been defined in appellate court cases and now confirmed by the Court. Demand response - payments to consumers to reduce electricity consumption - was an excellent candidate to be this issue's acid test. Demand response is not a new invention, ${ }^{50}$ as it has been around for decades. In its present form, FERC is allowing intermediaries $^{51}$ to bid demand reductions into the wholesale electricity markets it controls as the equivalent of energy or capacity (the ability to provide energy when called upon). "By pulling together demand reductions from a number of retail customers, an aggregator enables individual customers to take part in the market when they otherwise could not do so." 52

What made demand response in the wholesale markets contentious is not what it is so much as what it is not. It forced a judgment about whether markets should trade something other than commodity energy. Demand response providers are not "public utilities" under

48 FERC v. Elec. Power Supply Ass'n, 136 S. Ct. 760, 774 (2016).

49 Business Practice, BUSINESSDICTIONARY, http://www.businessdictionary.com/ definition/business-practice.html (last visited Jan. 24, 2016).

50 Eric Hirst, Price-Responsive Demand in Wholesale Markets: Why Is So Little Happening?, 14 ElECTRICITY J. 25, 26-27 (2001). Utilities began demand reduction programs known as "curtailment" and "peak shaving" in the 1980s and 1990s. Jon Wellinghoff \& David E. Morenoff, Recognizing the Importance of Demand Response: The Second Half of the Wholesale Electric Market Equation, 28 ENERGY L.J. 389, 394 (2007).

51 FERC's Order 745 applies only to demand response bid into wholesale energy markets by intermediaries known as "aggregators" or "curtailment service provider[s]" ("CSPs"). Demand Response Compensation in Organized Wholesale Energy Markets, Order No. 745, 134 FERC 9I 61,187 (Mar. 15, 2011).

52 "Most residential customers cannot interact directly with the wholesale markets, as market rules in RTOs and ISOs" require bidders to offer a minimum amount of energy, which forces small-scale customers to bid through CSPs. Eisen, Who Regulates The Smart Grid?, supra note 3, at 81. 
the FPA, 53 so allowing FERC to control them appeared to expand its reach beyond jurisdictional entities. Moreover, demand response is not merely a wholesale market resource, because in its aggregated form it represents the sum of numerous consumption reduction decisions. Looked at one way, demand response is the bidding of a resource into wholesale markets. From another, the consumption reductions can affect retail rates, which states set. As FERC put it delicately, jurisdiction over "demand response is a complex matter that lies at the confluence of state and federal jurisdiction." 54 Opponents raised other policy objections, viewing demand response in wholesale markets as inferior to true marginal cost pricing of electricity. ${ }^{55}$ Unfortunately, the electricity industry, unlike most others, does not have "dynamic pricing," 56 which has not been implemented to any great degree. ${ }^{57}$

FERC justified Order 745 (which required aggregators bundling demand reductions and bidding them into wholesale energy markets to be paid the same market price as generators ${ }^{58}$ ) and related agency

53 Demand response providers do not own or operate "facilities subject to the jurisdiction of the Commission." The FPA's definition of a jurisdictional "public utility," see supra note 27 , is not the same as the common understanding of a "utility." The Act defines a "public utility" as "any person who owns or operates facilities subject to the jurisdiction of the Commission," that is, "any person who owns or operates" facilities for the transmission of electric energy in interstate commerce and to the sale of electric energy at wholesale in interstate commerce. 16 U.S.C. § 824(e) (2012). Demand response providers do not satisfy this test.

54 Elec. Power Supply Ass'n v. FERC, 753 F.3d 216, 219 (D.C. Cir. 2014), rev'd and remanded FERC v. Elec. Power Supply Ass'n, 136 S. Ct. 760 (2016) (quoting Order 745).

55 James Bushnell et al., When It Comes To Demand Response, Is FERC Its Own Worst Enemy?, 22 EleCtRICITY J. 9, 10 (2009) (claiming that demand response programs "threaten to crowd out far superior approaches").

56 Id. at 11 .

57 In 2014, only about one percent of American residential consumers were using any form of dynamic pricing rates. Fed. ENERGy ReG. COMm'N, 2014 ASSESSMENT OF Demand Response and AdVAnced Metering, Staff Report 31 (2014), available at http://www.ferc.gov/legal/staff-reports/2014/demand-response.pdf; see Paul L. Joskow \& Catherine D. Wolfram, Dynamic Pricing of Electricity, 102 AM. ECON. REV. 381, 38384 (2012) (discussing the slow adoption of dynamic pricing); Matthew L. Wald, Power Savings of Smart Meters Prove Slow to Materialize, N.Y. TIMES (Dec. 5, 2014), http://www.nytimes.com/2014/12/06/business/energy-environment/power-savings-ofsmart-meters-prove-slow-to-materialize.html.

58 Demand Response Compensation in Organized Wholesale Energy Markets, Order No. 745, 134 FERC 9I 61,187 (Mar. 15, 2011); Eisen, Who Regulates The Smart Grid?, supra note 3, at 75 . Demand response providers are only compensated when it is cost effective to do so, under a "net-benefits test" developed by each ISO/RTO. Pierce, Demand Response, supra note 4. 
proceedings ${ }^{59}$ on the pillars of its FPA authority: the power to decide just and reasonable rates, and the power to remedy discriminatory practices affecting wholesale rates. ${ }^{60}$ Its stated purpose was to propose "a remedy to concerns that current compensation levels inhibited meaningful demand-side participation." 61 FERC judged that while demand response is not energy, it compares to it because it has numerous benefits for energy markets, such as improved reliability, reduced consumption, and reductions in carbon emissions. ${ }^{62}$

This looked to some like a power grab, and sparked considerable tension between FERC and its opponents (organizations representing generators, and some states). The D.C. Circuit's EPSA decision held that demand response was solely a retail-level activity, that FERC had no authority over it, and that giving FERC jurisdiction over demand response would have no boundaries; if Order 745 stood, FERC could regulate the steel and labor markets if it so chose. ${ }^{63}$ In the wake of the D.C. Circuit's EPSA decision, there was considerable uncertainty about demand response participation in wholesale markets. Some believed that FERC had overreached and can only promote electric grid innovation with new or revamped statutory authority. ${ }^{64}$

59 Order 745 built on the foundation of FERC's Order 719, which required ISOs and RTOs to revise their tariffs and allow demand response aggregator participation in the wholesale markets. Wholesale Competition in Regions with Organized Electric Markets, Order 719, 18 C.F.R. pt. 35 (2008) [hereinafter Order 719].

60134 FERC II 61,187, para. 112; see also Order Conditionally Granting MarketBased Rate Authorization and Providing Guidance, 130 FERC 9I 61,031, para. 32 (2010) (stating that FERC was construing demand response as a "practice that affects rates" in holding that EnergyConnect, a demand response provider, was subject to FERC jurisdiction); Order Assessing Civil Penalty, 144 FERC 9I 61,164, para. 71 (2013) (holding that an individual's fraudulent conduct in the ISO-New England demand response market was jurisdictional, using the same rationale).

61134 FERC 9I 61,187, para. 1. At one point, FERC had attempted to regulate demand response as a "sale" under FPA section 201, but by 2011, recognizing that no electricity was actually being sold, it had reversed its position. Order Conditionally Granting Market-Based Rate Authorization and Providing Guidance, 130 FERC II 61,031, para. 31 (2010).

62 Eisen, Who Regulates The Smart Grid?, supra note 3, at 71 (mentioning improved reliability and environmental impacts such as the reduced need to run polluting power plants).

63 Elec. Power Supply Ass'n v. FERC, 753 F.3d 216, 221 (D.C. Cir. 2014), rev'd and remanded FERC v. Elec. Power Supply Ass'n, 136 S. Ct. 760 (2016). In an article published in 2007, several years before Order 745's issuance and well before the EPSA decision, former FERC Chairman Jon Wellinghoff anticipated and refuted this slippery slope argument, referring to some of the case law discussed infra Part III. Wellinghoff \& Morenoff, supra note 50, at 404.

64 See generally Jacobs, supra note 2 (terming Order 745 "bypassing federalism"). 
A close look at the law developed over the past 100 years supports the Court's reading of the FPA. The Supreme Court's broad reading of "practices affecting rates" that empowers FERC to regulate demand response and other matters directly affecting the wholesale markets is no radical departure from the statutory text. To the contrary, it is a logical - and inescapable - conclusion from the lessons of a body of law developed over the past century. FERC $v$. EPSA is consistent with the focus on firms' conduct that has undergirded the approach to controlling regulated industries, demonstrating the regulatory structure's continuing adaptability. As the Court has now acknowledged, the statutory mandate continues unchanged, but has adapted to suit market realities.

\section{THE FOUNDATION OF MODERN AUTHORITY: "UNDUE DISCRIMINATION" AND "PRACTICES AFFECTING RATES" FROM THE RAILROAD ERA TO THE DAWN OF ELECTRIC INDUSTRY COMPETITION}

The origins of FERC's authority date to the Progressive Era. The "practices affecting rates" language originated in the 1906 Hepburn Act, a railroad regulation law that added section 15 to the Interstate Commerce Act ("ICA"), ${ }^{65}$ the forerunner of FPA section $205^{66}$ and nearly identical provisions in other regulatory statutes. After discussing that era, this Part turns to the time period beginning with the FPA's 1935 enactment, spanning the period of regulation of vertically integrated utilities to the rise of industry competition in the late 1980s and early 1990s. The final time period, discussed in the next Part, continues from there to the present day. Only after looking at all three can we arrive at a full picture of the modern view of "undue discrimination" and "practices affecting rates."

\section{A. Addressing Discriminatory Practices in Progressive Era Railroad Regulation}

Federal railroad laws created a regulatory juggernaut with strong federal powers. These statutes included the Interstate Commerce Act of 1887 ("ICA"), which established the Interstate Commerce Commission ("ICC"), and three Progressive Era statutes that strengthened it: the Elkins Act of 1903, the Hepburn Act, and the

65 Hepburn Act of $1906 \S 4$, 34 Stat. 584, 589-90, 49 U.S.C. § 15 (repealed 1978).

66 Global Crossing Telecomms., Inc. v. Metrophones Telecomms., Inc., 550 U.S. 45, 49 (2007) (noting that provisions of the Communications Act are nearly identical as well); Joshua Z. Rokach, FERC's Jurisdiction Under Section 205 of the Federal Power Act, 15 ENERGy L.J. 83, 83 (1994). 
Mann-Elkins Act of 1910.67 This government-administered scheme of regulation is now long gone from the national landscape, but the Hepburn Act and cases decided after its enactment developed two fundamental attributes of the "practices affecting rates" language. The first was that federal agencies could take action against a wide variety of discriminatory practices of regulated firms. The second was that statutes gave agencies broad discretion, but that discretion had limits.

The ICA represented a shift from the common law approach to regulation of common carriers. ${ }^{68}$ At common law, common carriers ${ }^{69}$ have a "duty to serve": they must carry all traffic, or face legal action for refusing to do so. As early as the 17th century, common carrier rates were required to be "reasonable." This followed from the duty to serve, as a common carrier could not pick and choose customers by quoting much higher rates to some customers than to those similarly situated. ${ }^{70}$ However, the "reasonableness" requirement was ineffective in preventing rate discrimination, due to proof problems and other weaknesses. ${ }^{71}$

"Reasonable" railroad rates were never uniform. Indeed, basic economics of $19^{\text {th }}$ and $20^{\text {th }}$ century railroad operation virtually dictated non-uniformity, ${ }^{72}$ and so the ICA's response was the lodestar

67 See Mann-Elkins Act of 1910, 36 Stat. 539; Hepburn Act of 1906, 34 Stat. 584; Elkins Act, 32 Stat. 847 (1903); Interstate Commerce Act of 1887, 24 Stat. 379. See generally Herbert Hovenkamp, Regulatory Conflict in the Gilded Age: Federalism and the Railroad Problem, 97 YALE L.J. 1017 (1988) (discussing railroad regulation laws).

68 Thomas W. Merrill, The Interstate Commerce Act, Administered Contracts, and the Illusion of Comprehensive Regulation, 95 MARQ. L. REV. 1141, 1141-42 (2012) [hereinafter The Interstate Commerce Act] (noting the ICA's institution of differences between ordinary contracts governing transportation in the common law regime, and tariffs in the statutory, administrative regime).

69 "Common carrier" is the well-known term that refers to those entities that hold themselves out to the public to carry goods or persons for hire, as distinguished from "private carriers." Am. COMmerce Ass'N, LAW OF COMMON CARriers, ABridged 1-5 (1918). Railroads were incorporated under state statutes, making them common carriers. Id. at 17.

70 Dewitt Clinton Moore, A Treatise on the Law of Carriers 160-61 (1914); J. Walter Lord, A Brief Review of the Subject of Federal Railroad Regulation, 181 N. AM. REV. 754, 755 (1905).

71 See Hovenkamp, supra note 67, at 1046; Lord, supra note 70, at 755.

72 Emory Richard Johnson \& Thurman William Van Metre, Principles of RAILROAD TRANSPORTATION 338-40 (1921) (discussing the reasons for differing railroad rates over different distances in depth); Hovenkamp, supra note 67, at 1035-37 (explaining this phenomenon); see also Sam Kalen, Muddling Through Modern Energy Policy: The Dormant Commerce Clause and Unmasking the Illusion of an Attleboro Line, N.Y.U. ENVTL. L.J. _ _ (forthcoming 2016) (manuscript on file with author) (observing that two different markets developed and states facilitated discrimination 
of "unjust" and "unreasonable" rates. ${ }^{73}$ Under the ICA, the agency could redress rates varying too dramatically from those offered to similar shippers in similar circumstances, without the procedural barriers of common law actions. ${ }^{74}$

\section{Remedying Discrimination: The Hepburn Act}

Besides excessive rate differentials, unlawful discrimination by railroads was understood at the time to include excessive rate differences and other preferences - railroad pooling, secret rebates, and drawbacks. ${ }^{75}$ Pools - cartels in which railroad members divided traffic and revenues among themselves - were not universally viewed as evil; indeed, they had been the subject of "a great debate waged among railroad economists and policymakers over whether [they] ... should be legal." 76 The ICA prohibited pooling, but by the early 1900s the practice had not completely diminished. Other practices, including drawbacks (rebates to favored shippers, plus rebates on rates paid by all other shippers) ${ }^{77}$ and rebates were widely criticized as

in the short-haul market).

73 See G. Edward White, Allocating Power Between Agencies and Courts: The Legacy of Justice Brandeis, 1974 DuKE L.J. 195, 199-200, 202 (discussing the political development of the "just and reasonable" rate standard in the Hepburn Act).

74 James B. Speta, Supervising Discrimination: Reflections of the Interstate Commerce Act in the Broadband Debate, 95 MARQ. L. REV. 1195, 1198 (2012) ("“T] concern in the nondiscrimination area has been to maintain equality of pricing for shipments subject to substantially similar costs and competitive conditions, while permitting carriers to introduce differential pricing where dissimilarities in those key variables exist."' (quoting Sea-Land Serv., Inc. v. ICC, 738 F.2d 1311, 1317 (D.C. Cir. 1984))).

75 There is an extensive literature on these unfair practices, much of it discussing the use of these practices by John D. Rockefeller's Standard Oil Company, but also referring to the practices as engaged in by other railroads. See, e.g., Standard Oil Co. v. United States, 221 U.S. 1, $42-43$ (1911); IDA M. TARbELl, THE History OF THE Standard Oil Company (1904); Charles Richard Van Hise, Concentration and Control: A Solution of the Trust Problem in the United States 226 (1921); Daniel Yergin, The PRIZE: The EPIC QUEST FOR OIL, MONey \& POWER 39 (1991) (discussing Standard Oil's controversial use of rebates and drawbacks); Lord, supra note 70; Michael Reksulak \& William F. Shughart II, Of Rebates and Drawbacks: The Standard Oil (N.J.) Company and the Railroads, 38 REv. INDUS. ORG., 267, 280-81 (2011).

76 Hovenkamp, supra note 67 , at $1039-40$ (noting that prominent economists and lawyers argued that pooling was essential to the railroads' survival).

77 YeRGIN, supra note 75, at 39; Reksulak \& Shughart II, supra note 75, at 280-81 (describing Standard Oil's drawback practices). For an interesting argument that drawbacks were actually justified, see generally Daniel A. Crane, Were Standard Oil's Railroad Rebates and Drawbacks Cost Justified?, 85 S. CAL. L. REV. 559 (2012). 
anticompetitive. ${ }^{78}$ Rebates came in several different forms, including "personal" discrimination (rebates to large shippers in exchange for their business) and rebates extended by vertically integrated railroads to their own parent or subsidiary firms. ${ }^{79}$ Another activity viewed as problematic was abuse relating to private railroad cars. ${ }^{80}$ Railroads did not keep a permanent supply of cars needed for shippers' use. Independent companies kept them and provided them as necessary. ${ }^{81}$ These firms faced no federal regulation, so problems arose, ranging from simple extortion to allotments of cars that favored some shippers over others, to secret rebates on private car charges. ${ }^{82}$

Opposition to secret preferences was a strong driver of federal regulation. The Elkins Act strengthened the ICA by ending rebates, ${ }^{83}$ but this was ineffective to end their pervasiveness, because the ICC lacked enforcement power. ${ }^{84}$ The result of a contentious Congressional debate and forceful personal advocacy by President Roosevelt for more federal power85 was the 1906 Hepburn Act. That law contained versions of three types of power that became common to regulatory agencies: power to set maximum - though not minimum — rates under the "just and reasonable" standard; 86 power

78 Hovenkamp, supra note 67, at 1046 (noting that railroads' preferences were opposed by "[n] early every person who wrote about railroads in the nineteenth and early twentieth century").

79 Id. at 1047; Reksulak \& Shughart II, supra note 75, at 280-81.

80 A 1905 article listed "private-car abuse" as one of three railroad "evils alleged by the shipping public to be prevalent, and which call for correction," the other two being "extortionate rates" and "[rate] discrimination." Lord, supra note 70, at 754 .

81 An example was refrigerated cars to ship perishable crops, which the railroads needed only seasonally. Id. at 763-64.

82 In his 1905 State of the Union Message, President Roosevelt blasted the abuses of the private car system, calling them "pernicious." Theodore Roosevelt's Fifth Annual Message, Am. PRESIDENCY PROJECT (Dec. 5, 1905), http://www.presidency.ucsb.edu/ws/ index.php? pid=29546\&st=theodore+roosevelt\&st $1=$.

83 Elkins Act \& 1, 32 Stat. 847, 847-48 (1903).

84 James W. Ely Jr., The Troubled Beginning of the Interstate Commerce Act, 95 MARQ. L. REV. 1131, 1132 (2012).

85 Thomas W. Merrill, Article III, Agency Adjudication, and the Origins of the Appellate Review Model of Administrative Law, 111 ColuM. L. REv. 939, 955-58 (2011) [hereinafter Article III] (discussing the debate over the Hepburn Act and President Roosevelt's involvement); see Theodore Roosevelt: Domestic Affairs, MILLER CENTER FOR AM. PRESIDENT, http://millercenter.org/president/biography/roosevelt-domestic-affairs (last visited Jan. 21, 2016).

86 Section 1 of the Hepburn Act provided that, "All charges made for any service rendered or to be rendered in the transportation of passengers or property as aforesaid, or in connection therewith, or for the receiving, delivering, storage, or handling of such property, shall be reasonable and just; and every unjust and 
to judge whether rates were just and reasonable (taking it from the courts, which retained power to review the ICC's rate decisions), 87 and power to end discriminatory practices. On this third point, ICA section 15, added by the Hepburn Act, provided:

That the Commission is authorized and empowered, and it shall be its duty, whenever, after full hearing ... it shall be of the opinion that any ... regulations or practices whatsoever of such carrier or carriers affecting such rates, are unjust or unreasonable, or unjustly discriminatory, or unduly preferential or prejudicial, or otherwise in violation of any of the provisions of this Act, to determine and prescribe what ... regulation or practice in respect to such transportation is just, fair, and reasonable to be thereafter followed. 88

The Congressional debate over the Hepburn Act reflected considerable interest in using this provision to stop specific unlawful practices. For example, Congressman Clayton observed that the new Act "will go far toward preventing secret practices, preferences, rebates, and the like, which have been so difficult to deal with, and which have really resulted in building up immense fortunes in the hands of those favored by such practices, preferences, rebates, and the like." 89

The primary mechanism for combating discrimination was the published tariff, which announced a carrier's terms and conditions of service. ${ }^{90}$ The tariff was far more than a simple rate schedule. As Thomas Merrill has explained, a tariff is an "administrative contract" 11 - a list of terms and conditions a firm submits and a regulatory agency approves. Announcing core policies and services ensures that all customers receive service under the tariff's terms and conditions, (in theory) protecting them from discrimination. ${ }^{92}$ Courts held that

unreasonable charge for such service is prohibited and declared to be unlawful." Hepburn Act of 1906 \& 1, 34 Stat. 584, 584-86; Clarence A. Miller, The Legislative EVOlution of THE INTERSTATE COMMERCE ACt 140 (1930); see generally 1 William J. KNORST, Interstate Commerce LaW ANd Practice 51-200 (1st ed. 1953).

87 Hepburn Act § 5, 34 Stat. at 590-92; see Merrill, Article III, supra note 85, at 965 (noting that the design of that provision presaged modern judicial review of agency decisions).

88 Hepburn Act \& 4, 34 Stat. at 589-90.

8940 CONG. REC. 1996 (1906). Similarly, Congressman Esch decried abuses of the private car system. 40 CONG. REC. 2004 (1906).

90 N.Y., New Haven \& Hartford R.R. v. ICC, 200 U.S. 361, 391 (1906).

91 Merrill, The Interstate Commerce Act, supra note 68, at 1142.

92 MCI Telecomms. Corp. v. AT\&T Corp., 512 U.S. 218, 229-30 (1994); see also id. at 1145 . 
providing service without a tariff, failing to file and publish a tariff before providing service, or deviating from an approved tariff, violated the ICA. ${ }^{93}$ This made secret preferences and other discrimination more difficult to implement, but did not completely end them.94 For example, carriers quickly learned to file tariffs that offered different rates to different shippers, based on competitive circumstances.

\section{Judicial Construction in the Pre-New Deal Era}

Almost immediately, courts were called upon to interpret ICA section 15, with several cases reaching the Supreme Court. These cases are hardly fusty relics of history, as they are often cited today. They settled important principles later enshrined in the FPA and that are still vital today: regulators have broad authority to remedy discrimination; discrimination refers to unlawful preferences or advantages; and "practices" must be construed broadly, with some limits, to enable regulators to reach a wide range of activities. ${ }^{95}$

The first major case, ICC v. Illinois Central Railroad, ${ }^{96}$ settled that the ICC could use its anti-discrimination mandate to remedy railroads' unlawful preferences, and that this mandate gave the ICC broad power over more behavior than the railroad evils originally identified as problematic. The case involved the ICA's requirement that a railroad have suitable rail cars to transport goods whenever reasonably demanded by a shipper. A railroad was only bound to provide cars as it might reasonably be expected to have in the ordinary course of its business. ${ }^{97}$ If it did not have enough, it would choose how to allocate them. Could the ICC issue an order forcing a different distribution?

The ICC issued just such an order, 98 and the Supreme Court upheld it, rejecting the railroad's argument that the ICC had no power to

93 Merrill, The Interstate Commerce Act, supra note 68, at 1145.

94 Paul Stephen Dempsey, The Rise and Fall of the Interstate Commerce Commission: The Tortuous Path from Regulation to Deregulation of America's Infrastructure, 95 MARQ. L. REV. 1151, 1164 (2012) (noting that unlawful practices persisted after the Elkins and Hepburn Acts).

95 Cases decided under the ICA have relevance in FPA cases, due to the settled principle of statutory construction that "where provisions of one statute have been adopted by another, the interpretation which has been authoritatively placed upon the former applies to the latter also." Hope Natural Gas Co. v. FPC, 196 F.2d 803, 807 (4th Cir. 1952); cf. Ivy Broad. Co. v. Am. Tel. \& Tel. Co., 391 F.2d 486, 490-91 (2d Cir. 1968) (observing that ICA cases retain their importance under the Communications Act).

96 ICC v. Ill. Cent. R.R., 215 U.S. 452 (1910).

97 MOORE, supra note 70, at 67-68.

98 Ill. Cent. R.R., 215 U.S. at 464-65. 
compel a particular distribution. To hold otherwise, the Court stated, "would require us to hold that Congress, in enlarging the power of the [c]ommission over rates, had so drafted the amendment as to cripple and paralyze its power in correcting abuses as to preferences and discriminations which, as this court has hitherto pointed out, it was the great and fundamental purpose of Congress to further." 99 "Abuses" of any sort were within the ICC's purview to address.

The second major case, 1916's United States v. Pennsylvania Railroad, the so-called "Tank Car Case,"100 involved the railroad's responsibility (if any) to procure private cars for its shippers. Two oil companies sought to have the ICC force the Pennsylvania Railroad to provide them tank cars for shipping oil. ${ }^{101}$ Tank cars were a significant improvement over barrel shipping, allowing for larger oil shipments at lower per-unit rates. ${ }^{102}$ At the time, however, the vast majority of oil tank cars were in private hands, ${ }^{103}$ and the Pennsylvania Railroad owned less than $3 \%$ of the national total. 104

The ICC ordered the railroad to furnish cars to the two companies. A lower court reversed the order, and the Supreme Court affirmed. Justice McKenna discussed at length the claim that the refusal to provide private cars was a "practice." The Court observed that the Hepburn Act had not defined the "practices 'affecting [such] rates" language. ${ }^{105}$ It was up to the Court to bring clarity, but the language that came next was anything but clear:

Let us test the contention and see where it takes us. The request was for a special facility, a combination of package and car, and the question, then, is whether the neglect to provide it or to furnish it was a 'practice' within the meaning of $\S 15$. The far-reaching effect of an affirmative answer is instantly apparent, and there must be hesitation to declare it from the

99 Id. at 477.

100 United States v. Pa. R.R. Co., 242 U.S. 208 (1916).

101 See id. at 219-20.

102 See id. at 211.

103 A Congressional report several years after the Tank Car Case, discussing subsequent legislative developments, called the inadequacy of private cars "notorious," and stated that, "[f]or years the increase in the equipment of the carriers had lagged behind the increase in the total demand for equipment." Railroad Revenues and Expenses: Hearings Before the Comm. on Interstate Commerce, 67th Cong. 2601 (1922).

104 Pa. R.R. Co., 242 U.S. at 231 (restating the ICC's conclusions of facts that the Pennsylvania Railroad owned less than 1,000 cars, and all other railroads east of the Mississippi owned 303, while the total nationwide was over 40,000).

105 Id. at 228. 
use of so inapt a word as 'practice.' Following a well-known rule of construction, we must rather suppose its association was intended to confine it to acts or conduct having the same purpose as its associates. And there were many such acts for which the word could provide, - practices which confused the relation of shippers and carriers, burdened transportation, favored the large shipper, and oppressed the small one. These have illustrations in decisions of the Commission. And this was purpose enough, remedied all that was deemed evil in privately owned cars of any type. Beyond that it was not necessary to go; beyond that there were serious impediments to going; and we cannot but believe that if beyond that it was intended to go, there would have been explicit declaration of the intent, with such provision as to notice and time and preparation as its consequences would demand; not ambushed in obscurity and suddenly disclosed by construction to turn accepted custom into delinquency, - a construction that could be disputed and was disputed. 106

In other words, the Supreme Court would not use the antidiscrimination mandate to compel railroads to purchase private cars. This would have created a virtually unlimited responsibility, expanding railroads' obligations well beyond the needs of two oil companies shipping in western Pennsylvania. ${ }^{107}$ Moreover, to require shippers to provide for their own private cars was not discrimination, as that was understood at the time. The railroad was not choosing among shippers, for example, by buying cars for some and not for others.

Nearly 100 years later, some courts saw only limitations in this language to a broad construction of "practices" ("[b]eyond that it was not necessary to go," "serious impediments," a construction "ambushed in obscurity and suddenly disclosed"). 108 Viewing the holding in context, however, it is neither surprising nor much of a limit on "practices." Indeed, what the Court did not do is more important today than its precise holding about tank cars. Justice McKenna did not alter or constrain the ICC's general statutory authority to remedy a broad range of practices. He confirmed it: the

106 Id. at 229.

107 The Court stated, "[i]f there be a duty [to provide private cars], it would seem necessarily to be universal. And such contention is growing." Id. at 229.

108 See infra notes 219-33 and accompanying text (discussion of Tank Car Case as limiting FERC's authority, in the California Independent System Operator case). 
ICC could remedy "many such acts" of discrimination. ${ }^{109}$ Practices were activities favoring one group of shippers over another unjustly; in the archaic usage "confused the relation," "relation" meant "relationship." 110 The ICA did not define "practices" and "affecting," and the fact that "many such acts" could be discriminatory demonstrated the terms' breadth and flexibility.

The core function of section 15 regulation was to control discriminatory practices favoring one group of shippers over another. That principle, not the specific holding about the private car system, is the Tank Car Case's most important contribution to modern law. Consider how the case was remembered in Northern Pacific Railway Co. v. United States, a lower court decision two decades later that summarized the meaning of "practices affecting rates" in the 1940s (that is, just after the FPA's enactment) as follows: "practice' as employed in the statute cannot have a meaning co-extensive with any exigency deemed to exist, or elastic enough to embrace everything a carrier may do [but] it does embrace those things that affect arbitrarily and unreasonably the purse of the shipper."111

Consistent with this interpretation, discriminatory practices in this era were individual railroads' actions giving undue preferences to specific shippers. "Practices" included specific evils (rebates, pools, and drawbacks) and other preferences. To ascertain whether practices were unlawful, the agency would measure conduct against terms and conditions listed in a tariff. Discrimination conducted in "secret," of course, was illegal. Otherwise, discrimination was viewed contextually. ${ }^{112}$ The mere existence of differential treatment was not sufficient per se to establish discrimination. Each practice would be examined in terms of whether the railroad was recovering its costs, and whether those costs were imposed arbitrarily and unreasonably on specific customers. ${ }^{113}$ Facts could be presented to justify specific differentials that on their face appeared improper. Also, if a railroad did not favor one class of shippers over another (as in the Tank Car Case, with no allegations that the railroad was buying cars for some

\footnotetext{
109 Pa. R.R. Co., 242 U.S. at 229.

110 For an earlier example of this usage, see 3 THE SCOTtish MAGAzine, AND CHurChman's Review 591 (Edinburgh: R. Lendrum \& Co., 1854), noting that Martin Luther "confused the relation of the two parts of the sacrament."

111 N. Pac. Ry. Co. v. United States, 41 F. Supp. 439, 443 (D. Minn. 1941), aff'd, 316 U.S. 346 (1942).

112 Speta, supra note 74 , at 1200.

113 See id. at $1198-200$.
} 
shippers and not for others), its activities would not be termed discriminatory.

However, courts imposed limits on the application of the antidiscrimination mandate. A relationship to jurisdictional rates was important. Thus, in the 1931 case of Missouri Pacific Railroad Co. v. Norwood, ${ }^{114}$ the Supreme Court held that the ICA's "practices affecting rates" language did not give the ICC the authority to regulate the number of men to be employed in crews, declining to consider a carrier's employment decisions "practices." A practice must be "connect[ed] with the fixing of rates to be charged and prescribing of service to be rendered[.]" 115

\section{B. "Discrimination" and "Practices Affecting Rates" from the FPA's Enactment Through the Rise of Competition and Modern Markets}

The law developed under the ICA created the foundation for the FPA. Congress modeled the FPA on the ICA, ${ }^{116}$ carrying its language forward almost verbatim ${ }^{117}$ to form the core of FERC's authority to regulate wholesale transactions. The FPA copied the ICA's rate-setting provisions, ${ }^{118}$ just and reasonable standard for wholesale rates, ${ }^{119}$ and prohibitions on discrimination or granting any "undue prejudice or disadvantage."

Two of the FPA's core sections mention "practice" or "practices." The first is section 205, where the FPA continued the tariff requirement. For the first several decades of regulation under the FPA, the primary instrument of regulation, as under the ICA, was a firmspecific tariff filing. ${ }^{20}$ FPA section 205(a) requires public utilities (as defined in the statute) to file tariffs setting forth schedules of rates and charges. Section 205(a) requires a jurisdictional utility to submit its

114 Mo. Pac. R.R. v. Norwood, 283 U.S. 249 (1931), modified, 283 U.S. 809 (1931).

115 Id. at 257.

116 See Nw. Pub. Serv. Co. v. Mont. Dakota Util. Co., 181 F.2d 19, 22 (8th Cir. 1950), aff'd, 341 U.S. 246 (1951).

117 Congress incorporated nearly identical language in other New Deal-era statutes. Merrill, The Interstate Commerce Act, supra note 68, at 1145-46. These statutes included the Communications Act of 1934, the Motor Carrier Act (which regulated trucking), and the Natural Gas Act (which regulated the interstate natural gas industry). The ICA, as amended by the 1920 Transportation Act, continued to regulate railroads.

118 See David B. Spence \& Robert Prentice, The Transformation of American Energy Markets and the Problem of Market Power, 53 B.C. L. REv. 131, 142 (2012).

11916 U.S.C. \& 824d(a) (2012).

120 Cf. MCI Telecomms. Corp. v. AT\&T Corp., 512 U.S. 218, 220 (1994) (filing of tariffs was "the centerpiece" of the Communications Act's regulatory scheme). 
rates to FERC, and section 205(c) imposes other, more extensive filing requirements for "classifications, practices, and regulations affecting such rates and charges, together with all contracts which in any manner affect or relate to such rates, charges, classifications, and services." 121

The second mention is in FPA section 206(a), which mirrored ICA section 15. As noted above, it provides a mandate for FERC to remedy a practice it finds "unjust" or "unreasonable": if "any rule, regulation, practice, or contract affecting such rate, charge, or classification is unjust, unreasonable, unduly discriminatory or preferential," FERC must "determine the just and reasonable rate, charge, classification, rule, regulation, practice, or contract to be thereafter observed and in force, and shall fix the same by order."122

This section analyzes the application of these provisions up to the beginning of the modern, market-based era. It begins with a discussion of the construction of "undue discrimination" in the first several decades after the FPA's enactment, noting its similarity to agency interpretation under the ICA. It then turns to evaluate a divergence in the interpretation of "practices affecting rates": the evolving use of "practices" to refer to the terms and conditions of a utility's tariff, rather than specific discriminatory practices, and the use of the FPA's filing requirement to fix the extent of FERC's authority.

\section{Agency and Judicial Construction of "Undue Discrimination"} After the FPA's Enactment

For decades after the FPA's enactment, the FPC interpreted section 206 much as the ICC had remedied railroad discrimination. This need not have been the case. The electric industry's economics, and the circumstances under which federal regulation began, were different from those of the railroads. As Professor Merrill explains, the administrative contract "got its start in an industry characterized by a mixture of competitive and monopolistic routes, where differential pricing (i.e., 'discrimination') was rampant, [but] it proved to be equally popular in industries with natural monopoly characteristics ...."123 As noted above, the FPA aimed to close the Attleboro gap and provide for national regulation of the utility industry, not to remedy specific discriminatory practices. There was no indication that the anti-discrimination mandate should change to

12116 U.S.C. $\$ 824 d(c)$

122 Id.

123 Merrill, The Interstate Commerce Act, supra note 68, at 1146. 
suit the differences between industries, and the statutory structure was simply carried over intact. Giving FPC broad anti-discrimination powers suggests these provisions had worked well up to this point, and the inclusion of nearly identical language in other New Deal-era regulatory statutes further supports this view. ${ }^{124}$

Judicial standards for defining and addressing discrimination carried over to the utility setting, and ICA precedents were routinely cited in utility cases. ${ }^{125}$ "Undue discrimination," in an industry of vertically integrated utilities facing no competition, meant unlawful differences in rates, terms, and conditions by individual utilities among their customers. This test looked to the tariff to ensure that the utility provided like rates, terms, and conditions of service to similarly situated customers. ${ }^{126}$ Utilities could not favor a class of customers, unless specific factual differences justified different rates or terms and conditions of electricity service. ${ }^{127}$ As in the case of the railroads, the FPC conducted fact-specific inquiries in individual cases.

As under the ICA, "undue" or "unreasonable" discrimination was prohibited, but not all rate differences. If "the record exhibit[ed] factual differences to justify... differences among the rates

124 Examples of this are found in communications and airlines regulation. The Communications Act of 1934 removed regulation of telephone, telegraph, and radio industries from the ICC (which received some authority under the Mann-Elkins Act), and gave it to the new Federal Communications Commission. See Essential Commc'ns Sys. Inc. v. Am. Tel. \& Tel. Co., 610 F.2d 1114, 1117-19 (3d Cir. 1979) (detailing early regulation of telecommunication and railroad industries); STUART N. BROTMAN, COMmunications LaW AND PRACTice \& 4.01[2] (1995 ed.) (describing powers given to the ICC to regulate telephone and telegraph services under the Mann-Elkins Act).

Section 201(b) of the Communications Act incorporated the "practices affecting rates" language, empowering the FCC to prohibit an "unjust" or "unreasonable" practice. See 47 U.S.C. § 201(b) (2012); Global Crossing Telecomms., Inc. v. Metrophones Telecomms., Inc., 550 U.S. 45, 58 (2007).

The Civil Aviation Act of 1938 and subsequent Federal Aviation Act of 1958 (Pub. L. No. 85-726, 72 Stat. 731 (1958)) regulated the airlines through regulatory tariffs; section 1002(d) of the latter statute (now repealed) incorporated the "practices affecting rates" language.

125 See, e.g., St. Michaels Utils. Comm'n v. Fed. Power Comm'n, 377 F.2d 912, 915 (4th Cir. 1967) (citing five cases decided under the ICA).

126 See Pub. Serv. Co. of Ind. v. FERC, 575 F.2d 1204, 1211-12 (7th Cir. 1978).

127 New Eng. Power Pool, 67 FERC 9I 61,042, 61,132 (1994); St. Michaels Utils. Comm'n, 377 F.2d at 915; cf. Eisman v. Pan Am. World Airlines, 336 F. Supp. 543, 546 (E.D. Pa. 1971) (concluding, in a case involving the propriety of student and youth air fares, that the Civil Aeronautics Board could make fact-specific inquiries as to whether differences in fares for the different classes of travelers were warranted under that standard). 
charged,"128 courts would not upset FERC's findings that utilities' rate differences were justified. A typical case holding that no discrimination existed under FPA section 206 despite differences in rates was St. Michaels Utilities Commission v. FPC,129 a 1967 Fourth Circuit case upholding a utility's difference in charges to two different classes of customers. This construction of "discrimination" looked no different from that of the early railroad cases.

\section{Post-FPA Changes in "Practices Affecting Rates"}

While the original understanding of discriminatory conduct carried over to the FPA setting, the interpretation of "practices" evolved from its original meaning of addressing discriminatory activities. In judicial decisions and agency interpretations, the focal point for defining practices shifted to interpreting section 205(c)'s filing requirement. As Justice Breyer observed in the 2007 Global Crossing Telecommunications $v$. Metrophones Telecommunications decision about the Communications Act's nearly identical provision, "the word 'practice' in [Communications Act] \& 201(b) traditionally applied to a carrier practice that (unlike the present one) is the subject of a carrier tariff - i.e., a carrier agency filing that sets forth the carrier's rates, classifications, and practices." 130 The FPC - and other agencies using provisions derived from the ICA - reasoned that filing standard practices or procedures in a tariff furthered the anti-discrimination purpose.

The few reported decisions in the post-New Deal decades that interpreted the "practices affecting rates" language reflected a contract interpretation theme, as courts grappled with how much detail tariffs should contain. "Practices" were the core of the utility-customer relationship. So did everything have to be spelled out in detail, or could some utility conduct be inferred? Specifying terms and conditions with less precision might threaten the level playing field on which consumers received service. However, if utilities had to spell out their activities in too much detail, it might burden them

128 Pub. Serv. Co. of Ind., 575 F.2d at 1211.

129 Alabama Elec. Coop. v. FERC, 684 F.2d 20, 21 (D.C. Cir. 1982) (requiring FERC to grant cooperative customers an opportunity to prove dissimilarity where the same rates charged by utility to cooperative and municipal customers produced different rates of return); St. Michaels Utils. Comm'n, 377 F.2d at 912; Portland Gen. Exch., Inc., 51 FERC 9I 61,108, 61,245 n.62 (1990).

130 Global Crossing Telecomms., Inc. v. Metrophones Telecomms., Inc., 550 U.S. 45, 57 (2007). 
excessively: did a regulator really need to know how many office staff a utility employed?

FPC's approach was a case-by-case inquiry it called the "rule of reason." 131 It did not insist that tariffs describe all "routine" utility practices, but balanced the benefits to consumers against the burdens on utilities of filing procedures, policies, or practices. An often-quoted agency decision was the 1965 Michigan Wisconsin Pipe Line Company case. ${ }^{132}$ The case involved a gas pipeline company's service to customers via branch or lateral lines (lines that break off of main pipelines to transport gas to end users), and whether terms and conditions of the company's service for these lines should be included in its tariff. The FPC held this was required, stating that a natural gas utility was required to file documents establishing a "consistent and predictable course of conduct of the supplier that affects its financial relationship with the consumer."133

Typical of this era is Village of Winnetka v. FERC,134 a 1982 case in which a Chicago suburb purchased electricity from its utility when it could not produce enough in its municipal power plant. The utility's tariff did not spell out the conditions or timing of these sales in detail. When the utility changed those terms, the village filed a complaint with FERC. It argued the utility should amend its tariff to include the approach to energy sales it had maintained for seven years as a "practice," and could not depart from this approach without prior FERC approval. FERC rejected the complaint with a summary discussion. The D.C. Circuit cited the rule of reason and the Michigan Wisconsin standard defining "practice" as controlling, and vacated FERC's order, holding FERC had not adequately explained its reasoning as to why the particular course of conduct was not a "practice" under this standard.

As explained by then-Judge Scalia in the D.C. Circuit's 1985 City of Cleveland decision, a utility's tariff filing need only include practices that affect rates "significantly." FERC had issued an order requiring a utility to file rate schedules with details about its provision of electric service to Cleveland. The city wanted the utility to set forth its

131 Town of Easton v. Delmarva Power \& Light Co., 24 FERC 91 61,251, 61,531 (1983).

The similarity to the "rule of reason" test in antitrust law occasionally caused judicial confusion. See Transwestern Pipeline Co. v. FERC, 820 F.2d 733, 741 (5th Cir. 1987) (rejecting the application of antitrust standards in reviewing FERC's actions).

132 Mich. Wis. Pipe Line Co., 34 F.P.C. 621 (1965).

133 Id. at 626.

134 Vill. of Winnetka v. FERC, 678 F.2d 354 (D.C. Cir. 1982). 
practices in even more detail. The D.C. Circuit upheld FERC's order accepting the utility's compliance filing, stating in part,

[T] here is an infinitude of practices affecting rates and service. The statutory directive must reasonably be read to require the [tariff disclosure] of only those practices that affect rates and services significantly,... It is obviously left to the Commission, within broad bounds of discretion, to give concrete application to this amorphous directive. ${ }^{135}$

Like the language of Michigan Wisconsin, this struck a balance in filing between detail and transparency, focusing on the connection between the utility's activity and rates. "Routine" activities did not have to be filed; "significant" ones did.136 What about activities by actors other than utilities that were significantly connected to rates, such as construction of new power plants? Neither City of Cleveland nor Michigan Wisconsin involved facts of this sort, so the question of whether these practices had to be filed went unaddressed. For years, then, there was a pragmatic connection between the filing requirement and the extent of FERC jurisdiction. It was simply assumed that the standard for filing was the last word on agency authority. 137

For years, no court analyzed the matter further. Unlike "just and reasonable" and "undue discrimination," which were the subject of many judicial decisions, "the filing requirements of $\S 205$ of the FPA did not receive such close scrutiny." 138 One reason was the existence of a "gentleman's agreement" between FERC and the utilities:

$[F]$ or certain categories of cases, the industry and the Commission staff over the years must have operated under a tacit understanding. Instead of arguing over which classes of agreements came within section 205, the industry filed those contracts covering transactions it thought (or the staff indicated) the agency would scrutinize. Companies held back

135 City of Cleveland v. FERC, 773 F.2d 1368, 1376 (D.C. Cir. 1985) (emphasis in original); cf. Pub. Serv. Comm'n of N.Y. v. FERC, 813 F.2d 448, 454 (D.C. Cir. 1987) (interpreting the nearly identical NGA ratemaking section and holding that FERC properly excused utilities from filing policies or practices that dealt only with matters of "practical insignificance" to providing service to customers).

136 See Rokach, supra note 66, at 86.

137 Cf. Richard McKenna, Preemption Under the Communications Act, 37 FED. Comm. L.J. 1, 18-19 (1985) (noting that the FCC's jurisdiction in the communications field in the years after the Communications Act's enactment was largely decided by tariff filings).

138 Rokach, supra note 66 , at 84. 
those in which the Commission would show no interest, even if the agreements were jurisdictional. ${ }^{139}$

For several decades, neither FERC nor the courts tested the limits of FERC's jurisdiction. The filing requirement was interpreted informally under this "tacit understanding," which helps explain the paucity of reported decisions. Important issues were unexplored in the FPA, the legislative history, or the cases. ${ }^{140}$

\section{THE TRANSITION TO COMPETITION AND MODERN APPLICATIONS OF "UNDUE DisCRIMINATION" AND "PRACTICES AFFECTING RATES"}

This situation changed dramatically with the advent of electric industry competition, when the meanings of "practices and "discrimination" both changed substantially, but in similar ways. The transformation of "undue discrimination" to a modern platform for addressing industry-wide conditions is well known and the subject of much commentary. ${ }^{141}$ Now, FERC $v$. EPSA confirms that the meaning of "practices affecting rates" changed as well.

Beginning with the first shift, FERC's interpretation of "undue discrimination" extended beyond an individual utility's conduct. In agency decisions and rules, FERC has taken an industry-wide view of its anti-discrimination mandate, using it to promote competition by establishing open access to the transmission grid, and prompting the creation of ISO/RTOs and the wholesale markets. As a result, a second transformation has taken place. FERC's oversight role has changed to overseeing market conditions to prevent discriminatory practices toward consumers. Instead of judging whether an individual firm's action is unjust, unreasonable, or discriminatory, it decides whether features of the wholesale markets' operation contribute to this effect. The Supreme Court has strongly endorsed these two interpretive shifts. ${ }^{142}$

139 Id.; cf. Boyd, supra note 1, at 1630 (observing that during this period, "[f] or the next several decades, the electric utility industry operated in a fairly stable economic and regulatory environment,... [under a] 'public utility consensus' forged among managers, regulators, and technical experts").

140 Rokach, supra note 66, at 99-100 (stating that "the legislative history of section 205(a) omitted any mention of this issue").

141 Eisen, An Open Access Distribution Tariff, supra note 1, at 1750-51; see also Richard J. Pierce, Jr., Realizing the Promise of Restructuring the Electricity Market, 40 WAKe Forest L. Rev. 451, 466-68 (2005); Joseph P. Tomain, The Past and Future of Electricity Regulation, 32 ENVTL. L. 435, 456-57 (2002) (discussing the justification of Order 2000 under the anti-discrimination mandate).

142 See, e.g., New York v. FERC, 535 U.S. 1, 1 (2002) (upholding Order 888 and 
"Practices affecting rates" authority has changed in similar fashion. First, the understanding of "practices" has transitioned from firmspecific tariffs to aspects of market operation. Second, the cases have given FERC broad authority to regulate activities relating to terms and conditions of market operation, even in some cases if they conflict with state law. Finally, FERC $v$. EPSA and the cases preceding it have set limits similar to those of the past, requiring a direct and significant relationship to wholesale rates.

Why did it take until 2016 for definitive confirmation of these shifts? There are several answers. In the market setting, the meaning of "practices" is not self-evident, in terms of who is covered or what conduct is. Before the market era, "practices" were those of individual utilities. In markets, whose actions can FERC regulate as "practices"? And what is the scope of "practices": could FERC regulate any activities that affect markets? In New York v. FERC, there was no need to decide whether "practices" had limits. Utilities' actions hampering transmission access came within FERC's unquestioned authority over transmission. ${ }^{143}$ Not so with an activity such as demand response, where the scope of FERC's authority is not spelled out in the FPA's text.

Another challenge stemmed from the fact that unlike other industries that deregulated, FERC kept tariffs, albeit in a different form. The transition to competition began later in the utility industry than in other deregulating industries. ${ }^{144}$ Yet almost alone among these industries, the utility industry kept the regulatory device for addressing discrimination - the tariff. ${ }^{145}$ FERC has encouraged

related agency actions, based in part on the agency's concern about discriminatory practices under sections 205 and 206).

143 See id.

144 See Eisen, Regulatory Linearity, supra note 26, at 549 (noting that the electric utility industry deregulated after the airline and telecommunications industries); Claire A. Watkins, Nuclear Power Rate Regulation After Eastern Enterprises: Are Ratepayers Being Taken for a Ride?, 28 B.C. ENVTL. AfF. L. Rev. 191, 208 (2000) (same conclusion).

145 See generally Joseph D. Kearney \& Thomas W. Merrill, The Great Transformation of Regulated Industries Law, 98 COLUM. L. REV. 1323 (1998) (describing the different policy path taken by restructuring of the electric power industry from the transition to competition in other regulated industries).

Domestic air fares were deregulated by the Airline Deregulation Act of 1978, Pub. L. No. 95-504 (1978), which removed the tariff requirement. The Motor Carrier Act of 1980, Pub. L. No. 96-296, 94 Stat. 793, completed final deregulation of the motor carrier industry and removed the requirement that carriers file their domestic passenger fares and rules with the Department of Transportation.

Most of the telecommunications field is regulated today without tariffs, but some aspects are still tariffed. The Telecommunications Act of 1996, Pub. L. No. 104-104, 
competitive markets and regulated the industry through broad pro forma tariffs that describe the markets' structure and operating rules for competitors and consumers, not by firm-specific tariffs. This made for difficulties in interpreting earlier cases. What relevance was there for judicial decisions about firm-specific tariffs when the nature of tariffs had changed? Moreover, what about the ICA cases that made distinctions about practices that could be termed discriminatory: what significance, if any, did they have in the wholly different context of the modern wholesale markets?

This Part discusses a standard for FERC's jurisdiction in wholesale markets that addresses these questions and is consistent with both FERC $v$. EPSA and the underlying movement in the law: FERC may regulate those practices which impact the wholesale markets directly or are integral to the proper functioning of the wholesale markets, but not practices that are only remote or insignificant in their connection to these markets. As discussed in this Part, this expanded understanding of FERC $v$. EPSA's "directly affecting" principle squares with the historical interpretations of "practices" and cases decided by the Supreme Court and D.C. Circuit during the modern, market-based era. Moreover, it is also similar to the evolution of the interpretation of "undue discrimination," giving FERC its proper role in addressing the challenges posed in modern markets.

\section{A. Evolution of "Undue Discrimination" to an Industry-Wide Focus}

By the 1980s, a modern approach to "discrimination" was needed. As FERC stated, "changing conditions in the electric utility industry, including the emergence of non-traditional suppliers and greater competition in bulk power markets," 146 required it. FERC's fact-specific test for undue discrimination allowed utility customers to challenge unfavorable rates by arguing that the utility offered improperly lower rates to its other customers. Protecting customers who purchased electricity at market-based rates required a different analysis.

110 Stat. 56, "detariffed" (opened to competition) many services in the telephone industry. Following detariffing, most services are handled competitively but some matters are still regulated by tariffs. See Mandatory Detariffing of Interstate and International Interexchange Services, FED. COMm. Commission (Aug. 8, 2008), https://transition.fcc.gov/wcb/ppd/detariffingl.html; Tariffs, FeD. COMm. Commission, https://www.fcc.gov/encyclopedia/tariffs (last visited Jan. 24, 2015).

146 Promoting Wholesale Competition Through Open Access Non-Discriminatory Transmission Services by Public Utilities; Recovery of Stranded Costs by Public Utilities and Transmitting Utilities, Order No. 888, 18 C.F.R. pts. 35, 385 (1996). 
FERC's statutory mandate remained the same, ${ }^{147}$ but the issues it faced in section 206 discrimination claims were different. Utilities owning transmission lines were perceived to offer terms and conditions for transmission service on their own systems more favorable than those offered to the upstart generators seeking to compete with them. This led to a raft of claims of undue discrimination by these generators to FERC that were grounded in unfair treatment when compared to the electric utility's use of its own transmission system, not in rate differentials for customers of the same utility.

FERC's groundbreaking response was the 1994 American Electric Power decision. ${ }^{148}$ This decision added a "comparability" requirement to the undue discrimination test, requiring a utility tariff to "offer third parties access on the same or comparable basis, and under the same or comparable terms and conditions, as the transmission provider's uses of its system."149 The "comparability" standard departed from the focus on an individual utility's customers, ${ }^{150}$ ensuring that utilities could not favor their own generation over that of independent generators when providing transmission service. It has no direct support in the FPA; "comparability" is found nowhere in the statute. ${ }^{151}$ Instead, FERC interpreted the section 205 ban on "undue prejudice or disadvantage" and "just and reasonable" requirement to mandate it. ${ }^{152}$

Later, FERC adopted the comparability standard on an industrywide basis in Order 888, requiring open access to the transmission grid. Order 888 contained the pro forma Open Access Transmission Tariff ("OATT"), which enshrined the principle of comparability. It required that public utilities subject to FERC's jurisdiction owning or controlling transmission lines provide open, non-discriminatory access on them to transmission customers. The OATT contains no

147 Cf. Global Crossing Telecomms., Inc. v. Metrophones Telecomms., Inc., 550 U.S. 45, 50 (2007) (noting that with competition neither Congress nor the FCC "abandoned traditional regulatory requirements").

148 Am. Elec. Power Serv. Corp., 67 FERC II 61,168 (1994).

149 Id. II 61,490.

15018 C.F.R. pts. 35, 385 (stating that, "the Commission broadened its undue discrimination analysis (which traditionally had focused on the rates, terms, and conditions faced by similarly situated third-party customers) to include a focus on the rates, terms, and conditions of a utility's own uses of the transmission system").

151 SCOTt Hempling, FERC's Demand Response DeCisions: What ARE the OPPORTUNITIES AND LIMITS? 4 (2013), available at http://sustainableferc.org/ wp-content/uploads/2013/09/Library/5-Scott-Hempling-Papers/FERC's\%20Demand\% 20Response\%20Decisions\%20(July\%202013).pdf.

152 Ala. Mun. Elec. Auth. v. FERC, 662 F.3d 571, 573 (D.C. Cir. 2011). 
firm-specific rates or service terms and conditions. Instead, it is a tariff made generally applicable to the entire class of transmission grid owners and operators. Each public utility was required to file the pro forma OATT, with only limited exceptions. ${ }^{153}$ Today, ISOs and RTOs - regulated public utilities as defined under the FPA - operate wholesale markets under this system. FERC revises the pro forma OATT with rules - such as Order 745 and 2007's Order 890 that reformed the OATT - that change market operations by requiring tariff changes. 154

FERC justified Order 888 under sections 205 and 206, and a D.C. Circuit decision in Associated Gas Distributors v. FERC that further emboldened it to interpret the anti-discrimination provision broadly. ${ }^{155}$ Applying comparability by requiring non-discriminatory open access to transmission services, FERC explained, "is critical to the full development of competitive wholesale generation markets and the lower consumer prices achievable through such competition."156 Order 888 changed the interpretation of "undue discrimination" in a fundamental way: it was not based on a showing of facts that demonstrated that an individual utility unduly discriminated in favor of specific customers against others, or had engaged in specific discriminatory behavior such as hampering access to transmission lines. This broad interpretation drew criticism, ${ }^{157}$ but is settled now. In New York v. FERC, the Supreme Court upheld Order 888, and its use

153 The pro forma OATT contains the minimum terms and conditions for nondiscriminatory transmission service, and every transmission-owning public utility must abide by the tariff in providing transmission services to itself and others. 18 C.F.R. \& 35.28 (2015) (describing requirements); see also Transmission Access Policy Study Grp. v. FERC, 225 F.3d 667, 727 (D.C. Cir. 2000).

Once their OATTs were effective, public utilities were allowed to file deviations from the OATT consistent with or superior to the pro forma OATT's terms and conditions. 18 C.F.R. pts. 35, 385.

154 Preventing Undue Discrimination and Preference in Transmission Service, Order No. 890, 72 Fed. Reg. 12,266, 12,294-12,489 (Mar. 15, 2007). Order 890 contained a number of reforms to the OATT, including new mechanisms for the determination of "available transfer capability" (in lay terms, the amount of space available) on transmission lines.

155 See Associated Gas Distribs. v. FERC, 824 F.2d 981 (D.C. Cir. 1987), cert. denied, 485 U.S. 1006 (1988).

15618 C.F.R. pts. 35, 385.

157 William L. Massey, Robert S. Fleishman \& Mary J. Doyle, Reliability-Based Competition in Wholesale Electricity: Legal and Policy Perspectives, 25 ENERGY L.J. 319, 327 (2004) (noting that Order 888 provoked "much skepticism outside the agency"). 
of the undue discrimination provisions to reach conduct preventing open access to the transmission lines. ${ }^{158}$

Courts have also confirmed that FERC's authority now extends to remedying discrimination in wholesale market operations. To cite one example, FERC polices market power abuses to protect consumers. ${ }^{159}$ In FERC's major contemporary rulemakings, the focus is on whether the market system has systemic shortcomings, creating discrimination. This interpretive evolution is not surprising. FERC's authority to oversee markets for discrimination is directly comparable to the original goal of regulation: remedying anti-competitive behavior. It continues the agency focus, dating to the ICA, on protecting consumers by fostering awareness of matters that can directly influence rates, and curbing or checking those actions that cause undue discrimination among classes of market participants and as a result cause rates to be unjust or unreasonable. The light shines "on particular transactions and activities, not on particular persons,"160 and the core concern is still "the role being played by any given person or entity and the transaction being regulated." 161

But questions about interpreting "practices" remained. When FERC finds "practices affecting rates" are discriminatory, it can order a remedy such as Order 745 . That begs the central question: what practices may FERC regulate?

\section{B. Evolution of "Practices Affecting Rates" in the Modern Era}

As the Supreme Court has now stated, the meaning of "practices affecting rates" has evolved as well to center regulatory attention on

\footnotetext{
158 New York v. FERC, 535 U.S. 1, 2 (2002).

159 See Morgan Stanley Capital Grp., Inc. v. Pub. Util. Dist. No. 1 of Snohomish County, 554 U.S. 527, 535 (2008); Richard B. Miller, Neil H. Butterklee \& Margaret Comes, "Buyer Side" Mitigation in Organized Capacity Markets: Time for a Change?, 33 ENERGY L.J. 449, 455 (2012). Specific analyses of FERC's role in dealing with market power abuses in the California wholesale electricity markets include Spence \& Prentice, supra note 118, at 159, and Jacqueline Lang Weaver, Can Energy Markets be Trusted?: The Effect of the Rise and Fall of Enron on Energy Markets, 4 Hous. Bus. \& TAX L.J. 1, 52 (2004). Cf. Speta, supra note 74, at 1195-96 (discussing the potential for application of nondiscrimination principles to the regulation of broadband); Barbara van Schewick, Network Neutrality and Quality of Service: What a Nondiscrimination Rule Should Look Like, 67 STAN. L. REV. 1, 1-2 (2015) (discussing the potential for application of nondiscrimination principles to regulation of the Internet).

160 Brief of the Microgrid Resources Coalition as Amicus Curiae in Support of Petitioners and in Support of Reversal at 12, FERC v. Elec. Power Supply Ass'n, 136 S. Ct. 760 (2016) (No. 14-840).
}

161 Id. at 13. 
market conduct, giving FERC authority over core functions of the markets relating directly to jurisdictional rates. This was no overnight shift, but was decades in the making.

\section{FERC Interprets "Practices" for Section 205 Filings: The Prior Notice Order}

The modern evolution of "practices affecting rates" authority began just before Order 888's promulgation, with the 1993 Prior Notice proceeding, ${ }^{162}$ FERC's first significant analysis of "practices." Events leading to Prior Notice started with the Public Utility Regulatory Policies Act of 1978, ${ }^{163}$ which promoted conservation and alternative forms of electricity production with financial incentives. This led to the rise of nonutility generators in competition with incumbent utilities, ${ }^{164}$ and pressure by those generators for access to the electric transmission grid. ${ }^{165}$ The 1992 Energy Policy Act responded with a provision stimulating growth of "merchant generators" (generators that produced electricity but served no retail customers) ${ }^{166}$ and a largely ineffective provision that authorized FERC to order electric utilities' "wheeling" of power (transmitting power for third parties) over their transmission lines. ${ }^{167}$ These developments, among others, prompted FERC to take steps to authorize wholesale sellers to charge market-based rates for their electricity sales. ${ }^{168}$

162 Prior Notice and Filing Requirements Under Part II of the Federal Power Act, 64 FERC 9I 61,139, order on clarification, 65 FERC 9I 61,081 (1993) [hereinafter Prior Notice].

163 Public Utility Regulatory Policies Act of 1978, Pub. L. No. 95-617 (codified as amended at 16 U.S.C. $\$ \S 2601-2645$ ). PURPA promoted conservation programs and alternative forms of electricity production by providing financial incentives to new, nonutility producers of renewable electricity and cogeneration, designated as qualifying facilities (QFs). Eisen, Regulatory Linearity, supra note 26, at 549. The requirements for QFs are found at 18 C.F.R. pt. 292.203.

164 Eisen, Regulatory Linearity, supra note 26, at 549-50; Hoecker \& Smith, supra note 8 , at 75 .

165 Hammond \& Spence, supra note 8, at 151

166 Market Oversight Glossary, Fed. ENERGy REG. COMmission, http://www.ferc.gov/ market-oversight/guide/glossary.asp (defining a "merchant generator" as "[a] generating plant built with no energy sales contracts in place"). As Professors Hammond and Spence note, this type of arrangement was virtually unheard of prior to 1980 . Hammond \& Spence, supra note 8, at 151; see also Eisen, Regulatory Linearity, supra note 26, at 550 (discussing the rapid growth of the wholesale power market in the 1990s).

167 Eisen, Regulatory Linearity, supra note 26, at 550; Hoecker \& Smith, supra note 8 , at 75 (noting procedural limitations of actions under the statute). Later, Order 888 replaced this provision.

168 Spence \& Prentice, supra note 118, at 147-48. The current requirements for 
The initial surge of market-based rate proposals led to the Prior Notice order, which dealt with section 205's filing requirement and discussed filing of non-jurisdictional "practices" connected to activities over which FERC did have jurisdiction. As such, it was an essential building block for FERC's broader authority over practices affecting rates.

Prior Notice emerged from FERC's 1991 Central Maine decision. ${ }^{169}$ Central Maine Power had fourteen market-based rate agreements to sell power at wholesale. These agreements had expired, but Central Maine had not filed them with FERC. Liability was clear - the utility had violated section $205^{170}$ - and the remedy seemed straightforward: FERC would announce that Central Maine was required to file its agreements before commencing service - not after it ended - and impose a penalty. FERC did just that.

If FERC had stopped there, the case would have had limited effect. However, FERC was concerned about filing delays by utilities selling both at market-based rates and at cost-based (that is, traditional) rates, and decided to comprehensively address these delays. ${ }^{171}$ To prompt compliance, it announced an amnesty period: sellers had 60 days after the Central Maine order to file their agreements.

FERC believed this would affect only a handful of "careless companies," 172 but the "file or else" position immediately created far more widespread uncertainty. FERC appeared to be systematically putting teeth into the filing requirement, which made utilities nervous. ${ }^{173}$ Utilities wondered whether they had to file documents they had assumed required no FERC approval, and there were many

market-based rate ("MBR") authority for wholesale sales of energy, capacity, and ancillary services are spelled out in FERC Order 697, promulgated in 2007. MarketBased Rates for Wholesale Sales of Electric Energy, Capacity and Ancillary Services by Public Utilities, Order No. 697, 72 Fed. Reg. 72,239, 72,240-72,241 (Dec. 20, 2007) (to be codified at 18 C.F.R. pt. 35); Spence \& Prentice, supra note 118, at 147-48.

Courts have upheld FERC's use of market-based rates. California ex rel. Harris v. FERC, No. 12-71958 at 7 (9th Cir. 2015) (holding that FERC used an improper methodology to evaluate market power in the California electricity crisis, but upholding FERC's basic MBR authority); California ex rel. Lockyer v. FERC, 383 F.3d 1006, 1017 (9th Cir. 2004). See generally Hammond \& Spence, supra note 8, at 152 ("FERC began to authorize most wholesale sellers of electricity to charge marketbased rates.").

169 See Cent. Me. Power Co., 56 FERC II 61,200 (1991).

170 Rokach, supra note 66, at 87.

171 Report of the Committee on Electric Utility Regulation, 15 ENERGY L.J. 505, 528 (1994).

172 Rokach, supra note 66, at 90 (noting that FERC received hundreds of filings).

173 See id. at 85. 
such situations. Consider a utility's contract to rent space on its pole to a phone company, which the utility might not file because FERC lacked jurisdiction over the phone company. Was it now required to file it? Surveying the situation, the Edison Electric Institute, the trade association representing major utilities, complained to FERC that, "confusion existed as to the extent of the FERC's jurisdiction over electric rates and which ancillary contracts the Commission would decide utilities must file under the FPA."174

Recognizing the problem, FERC convened an industry-wide technical conference, designed to develop policies for filing expired agreements ${ }^{175}$ but quickly expanding well beyond that. Utilities raised questions about the scope of FERC's jurisdiction over forty separate categories of activities. The eventual result was the Prior Notice order and its jurisdictional "Appendix"176 covering numerous specific situations and deciding with respect to each "how close a connection must the FERC make between an agreement and the activities Congress ordered the Commission to regulate in order to exercise jurisdiction." 177 FERC specifically linked its new thoroughness to ongoing industry changes. ${ }^{178}$

FERC's analysis of the "contributions in aid of construction" ("CIAC") issue illustrates Prior Notice's importance. CIAC involves a situation where a utility customer requests new facilities or upgrades to existing ones. The utility agrees to construct the upgrades, and the customer agrees to pay for the upgrades separately, that is, "contribute" up front to the construction cost. Many industry participants thought CIAC agreements, being construction contracts, did not have to be filed because they related to construction of transmission lines (regulated by state law) and not to transmission of electricity (over which FERC has jurisdiction).

FERC disagreed. In American Municipal Power-Ohio v. Ohio Edison ${ }^{179}$ decided before Prior Notice, Ohio Edison executed an agreement with American Municipal Power-Ohio ("AMP-Ohio") that provided for CIAC in exchange for Ohio Edison building transmission facilities to

174 Id. at 94.

175 Id. (observing that FERC was surprised by the number of jurisdictional issues raised); Report of the Committee on Electric Utility Regulation, supra note 171, at 528.

176 The Appendix is set forth at Prior Notice, supra note 162, 64 FERC 9III 61,984$61,996$.

177 Rokach, supra note 66, at 99.

178 See id. at 94.

179 Am. Muni. Power-Ohio, Inc. v. Ohio Edison Co. (AMP-Ohio), 57 FERC II 61,358 (1991), reh'g denied, 58 FERC 9I 61,182 (1992). 
interconnect Ohio Edison to an AMP-Ohio member. AMP-Ohio agreed to pay for these in advance. FERC held the CIAC agreement covered facilities that Ohio Edison used "in connection with" jurisdictional transmission service "because it involves facilities necessary in order to provide jurisdictional service; indeed, the new interconnection was intended to improve jurisdictional service that Ohio Edison provides to AMP-Ohio."180 Therefore, FPA section 205 required filing of the contract, even though FERC had no jurisdiction over the underlying construction.

In the Prior Notice proceeding, utilities sought to clarify this position. What if the facility being constructed was a generating plant? One utility contended that agreements for construction of generating plants are exclusively state jurisdictional matters, notwithstanding that the plant might connect to and use the interstate transmission grid.

The Prior Notice order and Jurisdictional Appendix responded,

[T] he question of our jurisdiction over a particular contract depends on whether the contract contains a rate or charge for or in connection with the transmission or sale of electric energy in interstate commerce, or whether the contract affects or relates to such rates or service.

[CIAC] agreements which must be filed for Commission [rate] review must relate to transmission in interstate commerce or sales for resale of electric energy in interstate commerce. . . .

As we noted earlier, even in ... our most recent order on the subject, we held that in order to come within our purview, the agreement must contain a charge connected to jurisdictional service.

This established several important principles and opened doors to the future. A direct connection to rates made a "practice" of a third party such as a construction firm jurisdictional, extending FERC authority to matters beyond the utility's own "price, availability, firmness, duration or other terms or conditions of any existing services." 181 Directness meant a connection measured in economic

180 Id. II 61,161; see also S. Cal. Edison Co., 98 FERC II 61,304, 62,301 (2002) (citing AMP-Ohio); Re W. Mass. Elec. Co., 61 F.E.R.C. II 61,182, 61,662-61,663 (1992) (citing AMP-Ohio and requiring filings of specified agreements as jurisdictional CIAC agreements).

181 Massey, Fleishman, \& Doyle, supra note 157, at 329 (quoting City of San Diego v. San Diego Gas \& Elec. Co., 51 FERC 9161,058 (1990)). 
terms: a document was jurisdictional if it contained a charge folded directly into wholesale rates.

Even more important was that the economic connection between the activity and jurisdictional service did not have to be immediate. FERC stated that it had "considerable flexibility in determining what rates and practices are 'for or in connection with,' 'affecting,' 'pertaining' or '[relating] to' jurisdictional service and, accordingly, must be filed ...." 182 The activity only had to be connected to rates or services over which FERC had jurisdiction, so it was sufficient if it would influence rates later. The critical link was that "the contract affects or relates to [wholesale] rates or service." 183 FERC marshaled cases and agency decisions to support this broad view of its authority. For example, it relied on an Eighth Circuit decision involving natural gas activities, which found FERC had authority over those activities undertaken "in connection with" jurisdictional service, ${ }^{184}$ and cited City of Cleveland. And it stated that filing was required even if state laws governed the underlying activities.

FERC stated this was its general position on its jurisdiction, which left the agency much discretion to resolve specific situations. For over twenty years, Prior Notice has been a cornerstone of the agency's approach to the filing requirement, cited often in agency proceedings. 185

\section{Toward a New Meaning of "Practices" and a Limiting Principle}

Prior Notice gave more depth to the filing requirement's purpose of transparency and awareness by requiring utilities to give FERC "prior notice" of a wider range of documents that could affect customers' rates. But its "directness" principle now extends more broadly to FERC's "practices affecting rates" jurisdiction in the market setting. As the Court has stated, FERC can assert authority to act on matters in modern wholesale markets "directly affecting" market rates.

Arriving at this conclusion required some interpretive building blocks. First, the meaning of "practices" needed to adjust once again,

182 Prior Notice, supra note 162, 64 FERC II 61,987.

183 Id. 9 I 61,990 (emphasis added).

184 Id. II 61,987 (citing N. Nat. Gas Co. v. FERC, 929 F.2d 1261 (8th Cir. 1991), cert. denied, 112 S. Ct. 169 (1991)).

185 An online research query yielded 463 decisions citing Prior Notice, the vast majority of which are FERC agency decisions. In addition to interpretive issues, issues relating to waiver of the notice requirement arise frequently. See, e.g., SPS Atwell Island, LLC, 152 FERC II 61,080, 61,463-61,464 (July 28, 2015) (rejecting a waiver request). 
to encompass aspects of market operation filed in ISO/RTOs' tariffs rather than in firm-specific tariffs. This was an issue Prior Notice could not have addressed, as it predated the markets. That adjustment happened without comment or controversy, as the law relating to tariff filings simply carried over from the pre-market era. Numerous contemporary agency decisions citing Prior Notice use its standard and the City of Cleveland "significance" requirement to determine the extent of FERC filing jurisdiction, ${ }^{186}$ without judicial challenge. And FERC has cited City of Cleveland numerous times as the standard for detail in ISO/RTOs' tariffs. 187

The more difficult matter concerns practices that are not filed in ISO/RTOs' tariffs but have "direct" and "significant" impacts on rates. Here, too, the direct connection and significance requirements of Prior Notice and City of Cleveland have carried over to the modern setting. Before FERC v. EPSA, courts expressed FERC's authority over these "practices affecting rates" in various different ways, without one consistent verbal formulation emerging. They gave FERC authority to regulate "key input[s] into the market-based mechanism," "matters most appropriately resolved by [FERC] as part of its overriding authority to evaluate and implement all applicable wholesale rate schedules," and terms that "directly and significantly affect the wholesale rates at which the operating companies exchange energy." The requirement of a direct economic relationship continued, as did the requirement that practices can be remedied only if FERC finds that a specific practice has caused undue discrimination.

FERC v. EPSA more precisely defines the shift from a focus on individual firms to market operations - and confirms and limits it. Prior to FERC v. EPSA, no single judicial decision addressed the scope of "practices affecting rates" as comprehensively as New York v. FERC did in the discrimination context. Instead, courts focused on specific practices rather than enunciating broad principles, making it sometimes appear as if the doctrine had developed haphazardly. To

186 See, e.g., Midcontinent Indep. Sys. Operator, Inc., 152 FERC 9I 61,073 (July 27, 2015) (agreement for development of a transmission line held jurisdictional, under the Prior Notice standard).

187 See, e.g., Cal. Indep. Sys. Operator Corp., 152 FERC II 61,063 (July 21, 2015) (requiring readiness criteria to be incorporated in the California ISO tariff); PJM Interconnection, LLC, 140 FERC 91 61,222 (Sept. 20, 2012).

Some decisions have allowed ISO/RTOs to specify certain market rules in ancillary documents such as business practice manuals, rather than in the tariffs themselves. Midwest Indep. Transmission Sys. Operator, Inc., 136 FERC II 61,038 (July 19, 2011); Midwest Indep. Transmission Sys. Operator, Inc., 147 FERC 91 61,268 (June 30, 2014) (requiring filing in the tariff rather than in a business practice manual). 
compound the problem, some decisions reached back to the past for insights without acknowledging historical shifts in the meaning of "practices," or occasionally took prior cases out of context or misconstruing them.

After FERC v. EPSA, FERC's authority is broad, like the historical authority over "practices." As the Court noted, the breadth of "practices" and "affecting" gives FERC tremendous flexibility, but also portends regulatory overreach if not carefully limited. Taken in their entirety, and viewed against the historical context, FERC v. EPSA and the cases that preceded it provide a limiting principle. The limiting principle inherent in the "practices" "directly affecting" rates formula can be summarized as this: FERC's "practices" jurisdiction extends to terms and conditions of the operation of wholesale markets which impact the wholesale markets directly and significantly, or are integral to the proper functioning of the wholesale markets, but not practices that have only a remote or insignificant connection. Applying this principle gives appropriate limits to reduce any lingering uncertainty about the scope of "practices" "directly affecting" wholesale rates and holds important implications for the jurisdictional dividing line between states and FERC.

\section{D.C. Circuit Cases Supporting and Limiting Authority over Practices Affecting Rates}

In numerous cases dating to the 1970s, the D.C. Circuit held FERC has authority to regulate practices directly affecting the wholesale markets. These cases began with a line of precedents strengthening FERC's authority to review rules related to capacity markets, in which owners of power plants are paid to have capacity available if needed in the future. ${ }^{188}$ Capacity markets are thought to be necessary because prices in other ISO/RTO markets are not always sufficiently high to keep existing plants from shutting down or to entice new plants to enter the market. Specifying the amount of capacity - the amount of generation needed on the system - has consistently been viewed as a factor within FERC's control. It can have impacts on states' authority

188 Hammond \& Spence, supra note 8, at 153; Paul L. Joskow, Competitive Electricity Markets and Investment in New Generating Capacity, MIT ECON. (June 12, 2006), available at http://economics.mit.edu/files/1190. Not all ISO/RTOs have forward capacity markets, although the PJM, New England and New York systems do. Capacity markets generally seek to have generation capacity online and ready to produce electricity at least one year ahead of time. RPM Base Residual Auction FAQs, PJM INTERCONNECTION, LLC, https://www.pjm.com/ /media/markets-ops/rpm/rpm-auction-info/rpm-base-residualauction-faqs.ashx (last visited Jan. 24, 2016) (three-year time horizon). 
to approve requests to build power plants, because it decides how much capacity is needed in the region (a factor states traditionally take into account when deciding whether power plants should be built). This did not stop the D.C. Circuit from supporting FERC's actions.

\section{Capacity Market Cases}

The first case involving FERC's authority to regulate capacity in wholesale transactions, Municipalities of Groton v. FERC, 189 involved the New England Power Pool Agreement ("NEPOOL"), a "power pool" that later transformed into ISO-New England.190 By the 1970s, twenty-one of these interconnected networks of transmission lines enabled coordination among neighboring utilities. ${ }^{191}$ Voluntary coordination arrangements could include a variety of services, ${ }^{192}$ and pooling had significant benefits for participating utilities, such as reduced investment in generation reserves (power plants kept in reserve to be fired up as needed) 193 and coordinated planning.

These power pools were voluntary, and governed by agreements among their members. In Municipalities of Groton v. FERC, the D.C. Circuit upheld FERC's authority to review a section of the NEPOOL Agreement that included a deficiency charge for each participating utility. ${ }^{194}$ If that utility's amount of generating capacity fell by more than $1 \%$ below the level set in the agreement, it owed a charge to the pool. The challengers argued that FERC lacked jurisdiction over this charge because it was designed solely as an incentive to encourage

189 Municipalities of Groton v. FERC, 587 F.2d 1296 (D.C. Cir. 1978).

190 In 1998, FERC granted the New England Power Pool's request for recognition as ISO New England, and approved its proposed market rules. New Eng. Power Pool, 83 FERC II 61,045, 85 FERC TI 61,379 (1998), order on reh'g, 95 FERC 9I 61,074 (2001).

191 For a discussion of power pools, see James F. Fairman \& John C. Scott, Transmission, Power Pools, and Competition in the Electric Utility Industry, 28 Hastings L.J. 1159, 1168-71 (1977).

192 Power pools can facilitate matters such as purchase and sale of reserve generating capacity, purchase and sale of electricity during emergencies and maintenance, and seasonal exchange of low-cost energy and centralized coordination of generation based on cost. Steve Isser, Electricity Restructuring in the United States: MARKets and POLICY FROM THE 1978 ENERGy ACt TO THE PRESENT 122-23 (2015).

193 "Reserve generating capacity" is "generating capacity available to meet peak or abnormally high demands for power and to generate power during scheduled or unscheduled outages." Glossary, U.S. ENERGy INFO. ADMIN., http://www.eia.gov/tools/ glossary/index.cfm?id=R (last visited Jan. 24, 2016).

194 Municipalities of Groton, 587 F.2d at 1301; see also Cent. Iowa Power Coop. v. FERC, 606 F.2d 1156, 1160 (D.C. Cir. 1979) (holding that FERC could condition approval of a power pool agreement on adoption of specific membership criteria). 
participating utilities to have enough generation, and did not represent a charge for a wholesale service or transmission. The court disagreed. It reasoned that "the Commission's inclusive jurisdictional mandate ... 'with respect to' jurisdictional transmissions, or 'affecting' such transmissions or services cannot be parsed so nicely." 195 The court then concluded: "It is sufficient for jurisdictional purposes that the deficiency charge affects the fee that a participant pays for power and reserve service, irrespective of the objective underlying that charge. This ... is well within the Commission's authority ...."196 What mattered was that the charge "affected" transmission rates within FERC's jurisdiction, not whether this incentive encouraged construction of generating plants over which FERC has no authority.

In more recent decisions, the D.C. Circuit confirmed this approach, concluding that FERC has authority to review a variety of rules related to capacity. In the 2009 decision Connecticut DPUC v. FERC, 197 the D.C. Circuit held that FERC had authority to approve the "Installed Capacity Requirement" ("ICR"), the core mechanism of the ISO-New England capacity market. The ICR is a determination of the minimum amount of capacity required on the regional grid, based on forwardlooking estimates of peak demand. ${ }^{198}$

The court reasoned that FERC had "practices affecting rates" jurisdiction over the ICR because "capacity decisions . . . affect FERCjurisdictional transmission rates for that system without directly implicating generation facilities." 199 The court added, based on Groton, that FERC "may directly establish prices for capacity-or . . . prices for failing to acquire enough capacity-even for the express purpose of incentivizing construction of new" 200 power plants. It determined the ICR was not a specific command to anyone to build a specific new power plant, but simply is an estimate of peak demand on the system. ${ }^{201}$ Thus, it was not direct regulation over generating facilities:

\footnotetext{
195 Municipalities of Groton, 587 F.2d at 1302.

196 Id.

197 Conn. Dep't. of Pub. Util. Control v. FERC, 569 F.3d 477, 479 (D.C. Cir. 2009), cert. denied, 558 U.S. 1110 (2010).

198 The ICR is the "measure of the installed resources that are projected to be necessary to meet both ISO New England's and the Northeast Power Coordination Council's reliability standards, with respect to satisfying the peak demand forecast for New England while maintaining the required reserve capacity." Installed Capacity Requirements, ISO-NEW ENGLAND, http://www.iso-ne.com/system-planning/resourceplanning/installed-capacity-requirements (last visited Jan. 24, 2016).

199 Conn. Dep't. of Pub. Util. Control, 569 F.3d at 484.

200 Id. at 482.

201 Id. at 481-82; see Miller, Butterklee \& Comes, supra note 159, at 452-53
} 
as the Supreme Court later reiterated, "[s] tates retained their ultimate authority over the construction of new generation facilities."202

Similarly, in the 2014 case of New England Power Generators Ass'n v. FERC, ${ }^{203}$ the D.C. Circuit evaluated FERC's authority to approve "buyer-side mitigation" measures (the power of large buyers to artificially depress market prices ${ }^{204}$ ) for the ISO-NE capacity market. This took the form of a test to determine whether a new power plant will unduly depress market prices. Certain new plants are subjected to a minimum bid requirement, known as a "minimum offer price rule" ("MOPR"), which could prevent them from clearing in the capacity market auction. This was controversial because of the potential adverse impact on market prices for certain types of power plants. 205

The New England court held that FERC had authority to require the buyer-side mitigation measures, reasoning that these measures were "a key input into the market-based mechanism" that FERC could regulate because mitigation matters are "affecting or relating to wholesale rates," and citing Groton and Connecticut DPUC. ${ }^{206}$ Once again, the D.C. Circuit stressed "that FERC's mitigation measures here do not entail direct regulation of facilities, a matter within the exclusive control of the states." 207

\section{Transmission Planning and Cost Allocation: South Carolina Public Service Authority}

The 2014 D.C. Circuit decision in South Carolina Public Service Authority v. FERC ${ }^{208}$ upheld FERC Order $1000,{ }^{209}$ which reformed the regional process for transmission planning and determining how to allocate the costs of new transmission lines. One part of the opinion addressed the removal of federal right of first refusal provisions, which are the rights of utilities to develop and own transmission lines needed

\footnotetext{
(criticizing the ISO-New England approach).

202 Elec. Power Supply Ass'n v. FERC, 753 F.3d 216, 234 (D.C. Cir. 2014), rev'd and remanded FERC v. Elec. Power Supply Ass'n, 136 S. Ct. 760 (2016).

203 New Eng. Power Generators Ass'n v. FERC, 757 F.3d 283 (D.C. Cir. 2014).

204 Miller, Butterklee \& Comes, supra note 159, at 456.

205 Id. at 462 (criticizing this test because states will not provide incentives for power plants that would not be paid in energy markets).

206 New Eng. Power Generators Ass'n, 757 F.3d at 290-91 (citing Conn. Dep’t of Pub. Util. Control, 569 F.3d at 478, 481).

207 Id.

208 S.C. Pub. Serv. Auth. v. FERC, 762 F.3d 41 (D.C. Cir. 2014).

209 Id. at 48-49; Transmission Planning and Cost Allocation by Transmission Owning and Operating Public Utilities, Order 1000, 18 C.F.R. pt 35 (2011).
} 
to serve customers in their own territories, even if other firms are willing to do so. 210 The South Carolina court noted that "[r]eforming the practices of failing to engage in regional planning and ex ante cost allocation for development of new regional transmission facilities... involves a core reason underlying Congress' instruction in Section 206." 211 The fact that regional transmission planning was a "practice affecting rates" was "illustrated" by the D.C. Circuit decision in Transmission Access Policy Study Group v. FERC, the decision upholding Order 888 later affirmed in New York v. FERC: each of these activities "directly affects or is closely related to jurisdictional rates." 212

This conclusion was appropriate. Transmission planning and cost allocation are "practices affecting rates" because they directly impact market rates. A system with less transmission is more congested and produces more expensive rates for delivered electricity. And FERC's authority extends to requiring power transmission planning and cost allocation methods, notwithstanding traditional state authority over transmission siting, because Order 1000 did not expressly intrude on states' authority to approve individual transmission lines. ${ }^{213}$ As in the capacity market cases, FERC can act, as long as it does not directly regulate matters reserved to the states.

Showing that the meaning of "practices" has evolved, the South Carolina court rejected an argument based on the Tank Car Case that would have constrained "practices" narrowly to those "that directly relate[] to the ... service provided customers." 214 As described above, this is how "practices" was interpreted in the early years after the FPA's enactment: the terms and conditions of individual firms' service. But the court rejected this interpretation, stating that, "because rights of first refusal are directly tied to rates charged for electricity transmission, such rights do directly relate to the service that is provided (i.e., the provision of electricity transmission service)." 215 As the court added, "[t]he challenged orders here provide... an

210 Scott Hempling, Order 1000 Narrows the "Right of First Refusal": Will Regional Processes Be COST-EFFECTIVE AND NONDisCRiminAtOry? 1 (2012), available at http://www.scotthemplinglaw.com/files/pdf/ppr_memo_rofr_hempling05032.pdf.

211 S.C. Pub. Serv. Auth., 762 F.3d at 57 (emphasis added).

212 Id. at 57, 64 (citing Transmission Access Pol'y Study Grp. v. FERC, 225 F.3d 667 (D.C. Cir. 2000), aff'd sub nom., New York v. FERC, 535 U.S. 1 (2002)) (holding that Order 888 aimed to remedy discriminatory practices).

213 Id. at 62; cf. Eisen, Who Regulates the Smart Grid?, supra note 3, at 123 (noting that, "[t]his authority to regulate in mixed jurisdictional settings alone supports upholding Order 745").

214 S.C. Pub. Serv. Auth., 762 F.3d at 74-75 n.7.

215 Id. 
economic principle that directly ties the practice the Commission sought to regulate to rates," and "[t]he direct economic relationship between rights of first refusal and rates forecloses any suggestion that characterizing these rights as practices affecting rates was somehow impermissible." 216

Prior to FERC v. EPSA, a more succinct summary of expansive "practices affecting rates" jurisdiction would have been hard to find. As in the capacity market cases, "practices" are not limited to actions taken by one utility - transmission planning and cost allocation are ISO/RTO-wide actions, requiring actions by multiple parties. This expansive view of authority is nevertheless consistent with the historical interpretation of "practices" which focused on actions impacting consumers. If it finds that transmission capacity in a region is inadequate or the costs of new lines are not allocated properly, FERC may act to blunt potential adverse impacts on electric utility customers. States may have concurrent regulatory authority (for example, their siting authority), but this is not dispositive of FERC's authority. As long as FERC can trace causation between practices and rates that consists of a direct - but not necessarily immediate economic connection to wholesale rates, it may regulate the practice. ${ }^{217}$

Note those words: "economic principle" and "direct economic relationship." This is Prior Notice reimagined for the modern setting. The effect on rates must be capable of measurement in economic terms, but need not be immediate. A right of first refusal over construction of a transmission line can impact wholesale rates, but it would take several intermediate steps to do so (for example, the line in question would have to be permitted by a state, and then built). This does not defeat FERC authority.

3. A Limiting Principle for "Practices Affecting Rates": Practices that Directly Relate to or Are Integral to the Proper Functioning of the Wholesale Markets

This discussion - and even FERC v. EPSA - leaves some important questions open to further interpretation. Which features of wholesale markets "directly affect" wholesale rates - and which do not?

216 Id. at 74-76 nn.7-8.

217 Hammond \& Spence, supra note 8, at 198 (observing that, "[t]he historical understanding of the regulatory contract seems to imply that FERC's authority to ensure rates are "just and reasonable" is limited to serving the economic interests of consumers and investors"). 
"Directly affecting" is broad; one can think of many routine "practices" of an ISO/RTO, such as personnel decisions, which would not directly impact markets. How should the line be drawn? That is, what connection between market operations and wholesale rates confers jurisdiction on FERC, and how close must that connection be?

Prior Notice and City of Cleveland have continuing vitality, even as firm-specific tariffs have given way to market tariffs. And focusing on a direct and significant connection between an activity over which FERC asserts jurisdiction and wholesale market rates is a limiting principle confirmed by judicial decisions. As the Supreme Court recognized, the standard's most precise enunciation is the D.C. Circuit's "common-sense construction of the FPA's language" in its 2004 California Independent System Operator v. FERC (CAISO) decision:218 "those methods or ways of doing things on the part of the utility that directly affect the rate or are closely related to the rate, not all those remote things beyond the rate structure that might in some sense indirectly or ultimately do so." 219

CAISO began in the California electricity crisis of 2000-2001.220 When rates skyrocketed, there was plenty of blame to go around. Some fell squarely on the grid operator (the "California ISO," or "CAISO"), which was faulted for poor oversight of markets that led to high electricity prices.221 When a corporation performs poorly, directors' heads' roll. FERC, California's governor, and the state legislature all decided CAISO needed a new Board unsullied by the crisis. And it got one, through a new California law that empowered the governor to appoint its five members. When CAISO then requested that FERC approve its market redesign proposal, FERC ordered it to implement a new Board structure that it had "proposed" earlier. ${ }^{222}$ It reasoned that a state-appointed Board could not be "independent of market participants," as Order 888 requires. CAISO and others promptly challenged FERC's action in the D.C. Circuit.

\footnotetext{
218 FERC v. Elec. Power Supply Ass'n, 136 S. Ct. 760, 774 (2016) (citing Cal. Indep. Sys. Operator Corp. v. FERC, 372 F.3d 395 (D.C. Cir. 2004)).

219 Cal. Indep. Sys. Operator Corp. v. FERC, 372 F.3d 395, 398 (D.C. Cir. 2004).

220 Scholars have amply documented the numerous policy choices that contributed to the crisis. See, e.g., Steven Ferrey, The Eagles of Deregulation: The Role of the Courts in a Restructured Environment, 32 ENVTL. L. 297 (2002).

221 See id. at 304.

222 Order Concerning Governance of the California Independent System Operator, 100 FERC 9161,059 (2002).
} 
The uniqueness and perceived egregiousness of FERC's action obviously piqued the D.C. Circuit. ${ }^{223}$ Using a Chevron analysis, the court barred FERC's interpretation of "practices affecting rates" under step one. The court found it "crystal clear" that interfering with a board's composition has no direct connection to rates.224 Then, it decided that the words surrounding "practice" in section 205 were "transactional terms," none of which "suggest a congressional concern with corporate governance or structure." 225 As the court observed:

It is quite a leap to move as FERC has from that context of transactional terms to an implication that by the word "practice," Congress empowered the Commission not merely to effect a reformation of some "practice" in a more traditional sense of actions habitually being taken by a utility in connection with a rate found to be unjust or unreasonable, but also to empower the Commission to reform completely the governing structure of the utility ....226

In response, FERC argued that it could regulate the "infinitude" (that is, all) of practices involved in the wholesale markets, plucking that word from City of Cleveland. The court rejected this, retorting sharply: "We are not biting." 227 It noted (correctly) that City of Cleveland did not fix the limits of FERC's jurisdiction, but cited it and Michigan Wisconsin for its limit on jurisdiction, although that case also dealt with the filing requirement. ${ }^{228}$

223 Its analysis begins with the following statement:

First, lest there be any mistake, FERC has done nothing less than order a public utility subject to its regulation to replace its governing board. We offer no citation to any comparable order by FERC, or any other similar federal regulatory body, because to the best of our knowledge, there is none.

Cal. Indep. Sys. Operator Corp., 372 F.3d at 398.

224 Id. at 400.

225 Id.

226 Id.

227 Id. at 401.

228 Compare id., with Calpine Corp. v. FERC, 702 F.3d 41, 47-48 (D.C. Cir. 2012), where the court rejected FERC jurisdiction over "station power" by relying in part on City of Cleveland. Station power is generally defined as "[e]nergy that is used to operate an electric generating plant... lighting, power, and auxiliary facilities, regardless of whether the energy is produced at the plant or comes from another source." See Glossary, U.S. ENERGY INFO. ADMIN., http://www.eia.gov/tools/glossary/ index.cfm?id=R (defining "station use," a term interchangeable with the Calpine Corp. court's working definition of station power). 
Not done yet, the court reached back into history. Citing the Tank Car Case, the court stated that the Supreme Court had interpreted "practices" there to refer "only to a railroad's terms of service and rejected a broader construction in which it could be contended... that every detail of railroad operation is a practice within the meaning of the Act."'229 This implies the Tank Car Case set a precise limit on defining "practices," which is off the mark. Also, it misses entirely the Tank Car Case's context involving private cars, and the case's preservation of the ICC's broad powers to define and remedy discriminatory practices.

Despite these errors, the CAISO court articulated a compelling test for "practices affecting rates," citing to the D.C. Circuit's previous decision in American Gas Ass'n v. FERC, 230 a case involving the natural gas industry. In upholding FERC's jurisdiction to issue portions of its natural gas restructuring orders, the D.C. Circuit had held that FERC's reading of "contracts affecting" its jurisdictional rates was restricted by the statute because "[c]ontracts that 'affect' a rate indirectly, merely by affecting the costs that determine what pipeline sales rates are permissible under the NGA's 'just and reasonable' standard, are beyond [the NGA's] reach." 231 Echoing that test, CAISO limited "practices" to include "those methods or ways of doing things on the part of the utility that directly affect the rate or are closely related to the rate, not all those remote things beyond the rate structure that might in some sense indirectly or ultimately do so."232 Replacing ISO board members was not a "practice," as it did not affect rates directly.

Streamlining this test in harmony with FERC v. EPSA, FERC's jurisdiction extends to "methods or ways of doing things" which "directly affect" the wholesale markets or are integral to the proper functioning of the wholesale markets, but not practices that are remote or insignificant in their connection to the markets. In the demand response context and elsewhere, the term "utility" in the CAISO test must be read to mean "the ISO or RTO." CAISO involved an entity regulated as a "public utility" under the FPA: the California ISO. The CAISO test can only apply directly to market activities of entities that FERC regulates as "public utilities," 233 and not to others, such as

229 Cal. Indep. Sys. Operator Corp., 372 F.3d at 402 (citing United States v. Pa. R.R. Co., 242 U.S. 208, 228-33 (1916)).

230 Id. at 403 (citing Am. Gas Ass'n v. FERC, 912 F.2d 1496 (D.C. Cir. 1990)).

231 Am. Gas Ass'n v. FERC, 912 F.2d 1496, 1506 (D.C. Cir. 1990).

232 Cal. Indep. Sys. Operator Corp., 372 F.3d at 403 (citing Am. Gas Ass'n, 912 F.2d at 1506).

233 Wellinghoff \& Morenoff, supra note 50, at 404 n.64. 
demand response providers. Non-jurisdictional entities subject themselves to FERC oversight by participating in the wholesale markets and thereby directly affecting rates.

Under this standard, a direct connection to rates is critical, because that means consumers can be harmed if FERC cannot regulate the activities in question. It stretches credulity to imagine that changes in the composition of an ISO board could harm consumers, although one could hypothesize that it might. (Suppose all appointed board members swore to prevent renewable resources from entering the market, thinking them unreliable.) By contrast, an activity such as transmission planning so directly affects rates that FERC should be able to oversee it.

FERC v. EPSA's focus on directness is consistent with historical interpretations of "practices affecting rates." It continues the focus from pre-1980 cases and from Prior Notice on a direct relationship to wholesale rates, 234 even though the focus has shifted from an individual utility's service to the ability of the wholesale market to serve customers. The directness standard derives further support from earlier cases that mention the closeness of the relationship between jurisdictional practices and wholesale rates. For example, in the 1988 Schneidewind case, the Supreme Court held that FERC had authority to regulate a natural gas company's capital structure because that is "related directly to the rates FERC allows it to charge."235

Another significant line of cases supporting the concept of directness is the "cost trapping" decisions from the 1980s that held that FERC has authority over "matters most appropriately resolved by [FERC] as part of its overriding authority to evaluate and implement all applicable wholesale rate schedules." 236 In these cases, FERC had made decisions about how to allocate costs of cancelled nuclear plants among utilities participating in multistate agreements. Some states felt the allocations were unfair to their ratepayers, and declined to "pass them through" into retail rates. The Supreme Court and several appellate courts held this was impermissible and that states had to give

234 Massey, Fleishman \& Doyle, supra note 157, at 329.

235 Schneidewind v. ANR Pipeline Co., 485 U.S. 293, 301, 308 (1988); cf. N. Natural Gas Co. v. State Corp. Comm'n, 372 U.S. 84, 92 (1963) (noting "the Federal [Power] Commission's authority to regulate the intricate relationship between the purchasers' cost structure and eventual costs to wholesale customers who sell to consumers in other States" (emphasis added)).

236 James W. Moeller, Requiem for the Public Utility Holding Company Act of 1935: The " "Old" "Federalism and State Regulation of Inter-State Holding Companies, 17 ENERGY L.J. 343, 377 \& n.325-26 (1996). 
binding effect to FERC's wholesale cost determinations;237 to hold otherwise would interfere with FERC's power to regulate "practices affecting rates." 238 FERC could review capacity cost allocations because "[c]apacity costs are a large component of wholesale rates" and "while these provisions do not fix wholesale rates, their terms do directly and significantly affect the wholesale rates at which the operating companies exchange energy ...."239

\section{APPLICATIONS AND IMPLICATIONS OF APPLYING THE STANDARD}

Because the directness standard could potentially be viewed as somewhat indeterminate, this Part clarifies it. The discussion here centers on "close call" cases that involve activity that appears to "directly affect" wholesale rates, but also seems to involve matters arguably outside of FERC's purview. Numerous activities appear to "affect" or "relate" to wholesale electricity markets. The limiting principle discussed above cabins FERC's authority to those practices that directly affect wholesale rates, system reliability, and the supply and pricing of energy at wholesale. By contrast, practices involving steel and labor - mentioned by the D.C. Circuit - do not have this kind of direct and significant effect on markets.

Where should the line be drawn? The discussion focuses on two different policies: demand response compensation under Order 745 (now upheld in FERC v. EPSA), and a hypothetical "carbon adder" that an ISO/RTO would propose to add an amount to the bid price of sellers in the energy wholesale market it administers "to better account for the full social costs of that electricity" in energy markets. 240 A related set of situations discussed here relates to preemption cases involving the electric grid, where the issue involves deciding whether FERC's actions preempt state laws designed to promote innovations in the electric grid.

Regarding the carbon adder, many have argued that the wholesale markets value low-cost electricity, not environmentally friendly electricity. They claim markets "do not price externalities and

237 Miss. Power \& Light Co., 487 U.S. 354, 356-57 (1988); Nantahala Power \& Light Co. v. Thornburg, 476 U.S. 953, 965 (1986).

238 See Miss. Indus. v. FERC, 808 F.2d 1525, 1539-44 (D.C. Cir. 1987), reh'g en banc granted in part, opinion vacated in part, 814 F.2d 773 (D.C. Cir. 1987), vacated, 822 F.2d 1103 (D.C. Cir. 1987), opinion reinstated, reh'g en banc denied, 822 F.2d 1103 (D.C. Cir. 1987), and opinion vacated in part on reh'g, 822 F.2d 1104 (D.C. Cir. 1987).

239 Id. at 1542 (emphasis added).

240 Hammond \& Spence, supra note 8, at 197-98. 
reliability well,"241 failing to account for externalities favoring fossil fuel-fired generation over other sources (notably renewables and nuclear). Some call for a carbon price to address this situation; others believe FERC lacks authority to impose one.242 Still others have called for a carbon adder as an option to facilitate compliance under the Clean Power Plan, which EPA explicitly contemplates in its final rule. ${ }^{243}$ FERC is likely reluctant to propose a carbon price, ${ }^{244}$ but if it chose to do so, could it ground one as a "practice affecting rates"? Providing further detail about the "directly affecting" standard yields the answer: it could.

\section{A. Four Factors for More Clearly Fixing the Limits of FERC's Authority}

This section discusses four factors to be used as guidelines in ascertaining whether specific activities fit within FERC's authority. It concludes that the Supreme Court properly found that FERC has the authority to make rules establishing demand response compensation, and also concludes that FERC could impose the hypothetical carbon adder. The four factors outlined here help define the dividing line between federal and state jurisdiction, based on the "directly affecting" standard.

1. FERC Is Regulating Wholesale Market Participants in Their Trading Activities

As the Court noted in FERC v. EPSA, "demand response programs work through the [regional grid] operators' regular auctions," and "every aspect of the regulatory plan happens exclusively on the wholesale market and governs exclusively that market's rules." 245 This confirms FERC's authority over the conduct of entities participating in markets by virtue of its approval of market pro forma tariffs and the rules contained in them. Thus, an activity is jurisdictional if it involves FERC regulation of market rules or other aspects of direct participation by jurisdictional entities (or those that could be, by meeting criteria for participation).

241 Hammond \& Spence, supra note 8, at 197; see Benjamin K. SOVACOOL, THE DiRTY ENERGy Dilemma: What's Blocking Clean POWER IN THE United States 4 (2008).

242 Moot, supra note 16, at 348.

243 Carbon Pollution Emission Guidelines for Existing Stationary Sources: Electric Utility Generating Units, 80 Fed. Reg. 64,661, 64,836 (Oct. 23, 2015) (to be codified at 40 C.F.R. pt. 60).

244 Hammond \& Spence, supra note 8, at 197-98.

245 FERC v. Elec. Power Supply Ass'n, 136 S. Ct. 770, 776 (2016). 
An example involves approval of requirements for participation in wholesale markets. For example, the PJM RTO criteria for demand response aggregators (which PJM calls "curtailment service providers," or "CSPs")246 include such matters as "appropriate operational infrastructure and a full understanding of all the wholesale market rules and operational procedures." 247 Wholesale markets also have detailed specifications for CSP participation. ${ }^{248}$

No state should be able to set these rules, as they are central to the markets' proper functioning. If, for example, states decided to set different requirements for trading on wholesale markets, the result would be chaos. Consider the analogy of a stock exchange, another type of interstate transactional marketplace where market operator rules are filed for approval with a federal regulator (in this case, the SEC). Stock exchanges regulate members' ability to participate in the markets - how they qualify as members (minimum capital requirements, for example), how they bid, how they handle and settle orders, and so forth. If these procedural features of the market were not subject to oversight by a central clearinghouse, it could lead to fraud or other dysfunctions. 249

The converse of this is that FERC cannot regulate conduct as "practices" that does not involve direct market participants. Recall the earlier example of the proposed shoe manufacturing plant in Massachusetts. 250 The shoe company would not face regulation under

246 PJM Interconnection, LlC, PJM Manual 11: Energy \& AnCillary Services MARKET OPERATIONS 109 (rev. Dec. 17, 2015), available at http://www.pjm.com/ / media/documents/manuals/mll.ashx.

247 Demand Response, PJM, http://www.pjm.com/markets-and-operations/demandresponse.aspx (last visited Jan. 24, 2016); PJM Tools FAQs, PJM, http://learn.pjm.com/ three-priorities/keeping-the-lights-on/pjm-tools-faqs.aspx (last visited Jan. 24, 2016); Retail Electricity Consumer Opportunities for Demand Response in PJM's Wholesale Markets 2, PJM, https://www.pjm.com/ /media/markets-ops/dsr/end-use-customerfact-sheet.ashx (last visited Jan. 24, 2016).

248 For example, PJM has detailed rules for CSP participation, such as requirements to identify specific demand reduction resources by location and load reduction capability. PJM INTERCONNECTION, LLC, supra note 246, at 110.

249 One exception to FERC's authority over the markets involves its limited ability to curb market manipulation, as shown by Hunter v. FERC, 711 F.3d 155 (D.C. Cir. 2013). In Hunter, the D.C. Circuit held that FERC lacked authority to fine a former natural gas trader for his allegedly fraudulent actions, determining that Hunter was subject to the jurisdiction of the Commodity Futures Trading Commission because his scheme operated solely within the commodity futures market. See William Scherman, John Shepherd \& Jason Fleischer, The New FERC Enforcement: Due Process Issues in the Post-EPAct 2005 Enforcement Cases, 31 ENERGY L.J. 55, 77-78 (2010).

250 See supra notes 48-49 and accompanying text. 
the FPA because it does not trade on the wholesale markets. State regulatory judgments about the siting and location of the proposed plant would not be supplanted, even if they might subsequently impact the wholesale price of electricity. For this reason alone, the D.C. Circuit erred when it found that FERC could theoretically regulate the steel and labor markets. This slippery slope argument ${ }^{251}$ had no support in the law, because it was inconsistent with the limitation to market participants. There is a robust body of literature on slippery slope reasoning, which illustrates the many problems in using it in cases such as this. ${ }^{252}$

As the Supreme Court noted, allowing FERC to regulate wholesale market participants does not completely strip states of their authority over such activities as demand response. Under FERC's Order 719, through its licensing authority, "any State regulator [could] prohibit its consumers from making demand response bids in the wholesale market." 253 This authority is similar to the securities context, where state blue sky laws' registration requirements govern broker-dealers' bona fides. Like that context, state licensing requirements cannot create an undue burden on participation in interstate markets, as the D.C. Circuit has confirmed in rejecting a state's demand response licensing requirement it felt intruded on FERC's authority. ${ }^{254}$ Neither could a state simply bar CSPs from participating in wholesale markets. Under a dormant Commerce Clause analysis, states that barred individual firms from doing business on an interstate market would

251 "A slippery slope always assumes a chain reaction of cause-effect events which result in some eventual dire outcome." Common Fallacies In Reasoning, FULLERTON.EDU, http://commfaculty.fullerton.edu/rgass/fallacy3211.htm (last visited Feb. 23, 2016).

252 See, e.g., Eugene Volokh, The Mechanisms of the Slippery Slope, 116 Harv. L. REV. 1027 (2003) (citing numerous articles and books).

253 FERC v. Elec. Power Supply Ass'n, 136 S. Ct. 770, 772 (2016); 18 C.F.R. $\S 35.28(\mathrm{~g})(\mathrm{l})(\mathrm{i})(\mathrm{A})$ (2015) (ISO/RTOs may not accept demand response bids where they are "not permitted by the laws or regulations of the relevant electric retail regulatory authority"). To take one example of how this might work in practice, a state could limit a CSP's license to implementing a retail-level demand response program on behalf of a utility.

Also, in that part of the nation without wholesale markets, demand response is done at the retail level only. Individual utilities are responsible for demand response in those states, and subject to state regulatory authority only.

254 Ind. Util. Regulatory Comm'n v. FERC, 668 F.3d 735 (D.C. Cir. 2012) (overturning an Indiana state law precluding customers from enrolling with aggregators without the state commission's prior approval); Eisen, Who Regulates The Smart Grid?, supra note 3, at 84 (describing barriers to demand response participation). 
almost certainly be impermissibly regulating these firms' reach beyond the state. 255

The carbon adder proposal would receive unequivocally favorable treatment under this guideline. If the carbon price were structured as an additional amount applying to sellers of generated electricity into the markets, it would meet this guideline because it applies to buyers and sellers, and not to any other entity.

2. FERC Is Addressing System Adequacy by Regulating the Quantity of Inputs to the Markets

The second factor derives from FERC's mandate to ensure the reliability of the wholesale power system. Throughout FERC v. EPSA, the Supreme Court emphasized that "[i]n promoting demand response, FERC did no more than follow the dictates of its regulatory mission to improve the competitiveness, efficiency, and reliability of the wholesale market."256 Writing for the majority, Justice Kagan summarized the myriad of ways that expanded demand response can improve system reliability. ${ }^{257}$ This focus on system reliability is consistent with earlier decisions, including the capacity market cases and South Carolina Public Service Authority. As the D.C. Circuit put it in Connecticut DPUC, "reasonable concerns about system adequacy ... [are] within the heartland of the Commission's section 206 jurisdiction."258 FERC may act to adjust regional supply and demand for electricity to ensure that rates are just and reasonable, as long as its actions are not arbitrary and capricious. The capacity market cases, for example, allow FERC to "indirectly incentivize action that it cannot directly require so long as it is otherwise acting within its

255 Steven Ferrey, Sustainable Energy, Environmental Policy, and States' Rights: Discerning the Energy Future Through the Eye of the Dormant Commerce Clause, 12 N.Y.U. EnVTL. L.J. 507, 631 (2004); Daniel K. Lee \& Timothy P. Duane, Putting the Dormant Commerce Clause Back to Sleep: Adapting the Doctrine to Support State Renewable Portfolio Standards, 43 ENVTL. L. 295, 310-11 (2013).

256 Elec. Power Supply Ass'n, 136 S. Ct. at 779.

257 Id. at 777 :

And in the Rule under review, FERC expanded on that theme. It listed the several ways in which "demand response in organized wholesale energy markets can help improve the functioning and competitiveness of those markets": by replacing high-priced, inefficient generation; exerting "downward pressure" on "generator bidding strategies"; and "support[ing] system reliability."

258 Conn. Dept. of Pub. Util. Control v. FERC, 569 F.3d 477, 482 (D.C. Cir. 2009). 
jurisdiction." 259 That "incentive" can affect an "input into the marketbased mechanism" 260 — the "input" in that case being the quantity of energy or capacity traded on the markets. If FERC finds there is not enough supply, for example, it may create incentives to prompt more bidding into the markets.

FERC $v$. EPSA confirms that FERC can provide incentives to adjust the quantity and quality of inputs to markets that it regulates to maintain system reliability, even if that impacts the states. Both demand response programs and capacity markets accomplish this by promoting specific system resources (demand reductions and supply). Critically, FERC can dictate the level of system resources, but cannot directly regulate the states. For example, FERC could not require construction of a specific power plant or condition wholesale sales on a requirement that retail distribution utilities adopt a specific pricing scheme. ${ }^{261}$ The ISO-New England ICR acts as an overall constraint on regional power plant construction and reduces states' flexibility, but does not specify the construction of any individual plant.

In FERC v. EPSA, the Court noted that FERC promulgated Order 745 in part because it believed the amount of demand response in wholesale markets was inadequate, which threatens the ability to meet system peak demand. ${ }^{262}$ According to the Court, it is therefore up to FERC, not the states, to establish the proper incentives to rectify this situation. ${ }^{263}$ To be sure, states could impact FERC's programs. For example, retail-level demand response programs could impact the wholesale markets: with more state-level demand response, an ISO/ RTO could adjust its projections of the amount of capacity needed in a region by the anticipated amount of demand reductions. That is neither prohibited, nor necessarily undesirable. In the interconnected grid, actors will affect each other, and FERC's plans to meet regional supply and demand will have to adjust to take account of matters that states control.

Now consider the case of the carbon adder. FERC could not simply call it an "environmental" initiative; FERC has limited latitude to directly consider environmental matters in its calculation of whether

259 Elec. Power Supply Ass'n v. FERC, 753 F.3d 216, 234 (D.C. Cir. 2014) (Edwards, J., dissenting), rev'd and remanded FERC v. Elec. Power Supply Ass'n, 136 S. Ct. 760 (2016).

260 See supra note 206 and accompanying text.

261 Cf. Elec. Power Supply Ass'n, 753 F.3d at 234 (making a similar argument).

262 Elec. Power Supply Ass'n, 136 S. Ct. at 777.

263 Id. 
rates are just and reasonable. ${ }^{264}$ Instead, it would need to make findings about its impacts on system adequacy. FERC could re-cast the increase in bid prices as a "reliability adder," as discussed most recently by Emily Hammond and David Spence. Actions designed to protect system reliability can take a wide variety of forms. To Professors Hammond and Spence, system adequacy "encompasses a suite of attributes (the ability to serve several different grid needs), and no single generation source has all of those attributes." 265 Thus, FERC could make findings that system adequacy would be imperiled without more electricity from nonfossil sources. FERC may judge, for example, that increased amounts of electricity generated from renewable sources are necessary to hedge against potential outages at fossil-fuel fired plants. Or, perhaps, that shorter lead times of certain renewable power plants would bring them on the system more quickly.

FERC would be within its authority to cast a carbon adder in these terms, because it would find support from both FERC $v$. EPSA and the capacity market cases. FERC would ground a judgment about this issue in terms of regional system adequacy, much as it did in those cases. In this analysis, the "input to the market mechanism" is slightly different: whether there is too much of a specific resource - and not enough of others - on the regional grid. This fits comfortably within a broad view of FERC's reliability authority. ${ }^{266}$

3. FERC Is Regulating Market-Wide Features to Remedy Discrimination Against One Resource in Favor of Another

As FERC v. EPSA concluded, "the Commission's justifications for regulating demand response are all about, and only about, improving the wholesale market." 267 This is wholly consistent with the numerous previous cases that have confirmed that FERC is best placed to address industry-wide changes, and that as a result, when FERC's remedies aim globally at the wholesale power system, "agency discretion is ...

264 Hammond \& Spence, supra note 8, at 198 n.301 (citing Grand Council of the Crees v. FERC, 198 F.3d 950 (D.C. Cir. 2000)).

265 Id. at 42.

266 Id. at 41-42 (noting that FERC's authority to consider reliability "is far more easily settled than its ability to directly consider environmental factors" and claiming that "a reliability and/or flexibility adder... might have better traction, both as a jurisdictional and as a political matter [than a carbon adder]"); $c f$. JOHN MOORE, THE SustainABle FERC PROJECT (2013), available at http://www.ferc.gov/CalendarFiles/ 20130911144750-Moore\%20Comments.pdf (discussing actions that FERC can take to promote added incorporation of renewables in capacity markets).

267 Elec. Power Supply Ass'n, 136 S. Ct. at 776. 
at its zenith." 268 Oversight of system-wide changes to market terms and conditions is squarely within FERC's purview. FERC v. EPSA and these "zenith" cases show that "practices affecting rates" has evolved from a meaning of practices of individual firms to those that affect the entire market. The "system-wide" limitation is important; the "practice" is the market structure and the remedy is to alleviate a bias against a specific resource. In New York v. FERC, for example, the Supreme Court observed "[w]ere FERC to investigate this alleged discrimination [regarding unbundled retail transmission] and make findings concerning undue discrimination," section 206 "would require FERC to provide a remedy for that discrimination." 269

To the Court, then, Order 745 was therefore justified because FERC found that market structures hampered full development of demand response, justified systemic regulation of this "practice affecting rates." As the Court noted, FERC compiled a lengthy record that existing conditions resulted in inadequate demand response participation. ${ }^{270}$ Order 719 was designed to "eliminate barriers to the participation of demand response in the organized power markets by ensuring comparable treatment of resources." 271 In turn, Order 719 was based on the policy established in the Energy Policy Act of 2005 that, "unnecessary barriers to demand response participation in energy, capacity and ancillary service markets shall be eliminated." 272 This Congressional policy statement is itself not a jurisdictional limit, but does provide further support for FERC's action. Then, Order 745 found that policy inadequate, and fixed the level of compensation to remove the barriers to demand response participation. ${ }^{273}$

Now consider the carbon adder. Under this factor, the failure to internalize the environmental externalities in the market as a whole is a "practice affecting rates" if it is justified with specific findings that barriers to participation by renewable resources in wholesale markets prevent those power plants from participating fully in wholesale markets. The fact that electricity generated from other fuels is lower-

268 Niagara Mohawk Power Corp. v. FERC, 379 F.2d 153, 159 (D.C. Cir. 1967); see Sacramento Mun. Util. Dist. v. FERC, 616 F.3d 520, 541 (D.C. Cir. 2010); La. Pub. Serv. Comm'n v. FERC, 522 F.3d 378, 393 (D.C. Cir. 2008); Towns of Concord, Norwood, \& Wellesley v. FERC, 955 F.2d 67, 76 (D.C. Cir. 1992); see also Eisen, Who Regulates The Smart Grid?, supra note 3, at 93; Wellinghoff \& Morenoff, supra note 50, at 409 (noting FERC's "broad remedial authority" in these circumstances).

269 New York v. FERC, 535 U.S. 1, 27 (2002).

270 Elec. Power Supply Ass'n, 136 S. Ct. at 770-72.

271 Order 719, supra note 59, at 64, 107.

272 Energy Policy Act of 2005, Pub. L. No. 109-58, \& 1252(f), 119 Stat. 594, 966.

273 Elec. Power Supply Ass'n, 136 S. Ct. at 771. 
cost and therefore clears wholesale markets more readily is not inherently discriminatory. As noted above, since the Progressive Era, rate differentials have been permissible in certain circumstances. For this reason, the barrier cannot simply be that the lower cost of electricity generated from fossil fuel sources does not account for the environmental externalities. ${ }^{274}$

A different sort of finding of discrimination against renewable resources is possible. While a full treatment is beyond the scope of the analysis here, one means of establishing discrimination might involve findings that applying buyer-side mitigation (discussed above in the New England case) to electricity generated from renewables "unfairly reduces their capacity value and costs consumers money." 275 In ISONew England, for example, the MOPR typically precludes any capacity market bids below minimum price thresholds set by the ISO, unless the ISO grants an exemption. In several recent proceedings, FERC has denied complaints requesting exemptions to the MOPR for renewable energy resources required by state public policies (such as renewable portfolio standards, which require a specific percentage of electricity to be delivered from renewable sources). ${ }^{276}$ Were it to conclude otherwise, there might be a foundation for a finding of discrimination.

4. FERC's Oversight Aims at Conduct that Directly and Significantly Affects Wholesale Rates

The final factor is whether the activity has direct and significant impacts on wholesale rates. Requiring an effect to be proximately connected with rates is central to "directness," This is consistent with South Carolina Public Service Authority's discussion of the "direct economic relationship" between the regulated practice and wholesale rates, and in harmony with Prior Notice's requirement of filing of documents that involved charges directly relating to rates. It is also consistent with the holdings in the capacity market cases, because there is a direct relationship between capacity requirement on regional systems and the payments in capacity markets. Finally, the

274 See Moot, supra note 16 , at 361.

275 Moore, supra note 266, at 8. ISO New Eng. Inc. \& New Eng. Power Pool Participants Committee, 150 FERC TI 61,120 (2015) (discussing the limited exemption from the ISO-New England MOPR).

276 See, e.g., New Eng. States Comm. on Elec. v. ISO New Eng. Inc., 142 FERC II 61,108 (2013), order on reh'g, New Eng. States Comm. on Elec. v. ISO New Eng. Inc., 151 FERC II 61,056 (Apr. 20, 2015). For a discussion of renewable portfolio standards, see JoEl B. EISEN ET AL., ENERGy, ECONOMICS AND THE ENVIRONMENT 758-67 (4th ed. 2015). 
requirement of significance provides more certainty: FERC would not have jurisdiction over activities that did not significantly impact market rates (licensing the shoe manufacturing plant, for example).

Both demand response and the carbon adder impact market rates directly and significantly without the actions of an intervening decision maker. As the FERC $v$. EPSA court recognized, in the case of demand response, "it is hard to think of a practice that does so more." 277 The Court noted that one of demand response's principal benefits is to serve as a safety valve to lower peak demand and rates. ${ }^{278}$ A market operator can bring demand response resources into the markets as needed to bring demand down and reduce spiking wholesale prices. ${ }^{279}$

With respect to the carbon adder, adding an amount to sellers' bids would fundamentally change the rate structure by altering market bidding. The wholesale markets operate on a "security-constrained, least-cost dispatch' or 'security constrained economic dispatch' ('SCED') rule." 280 The SCED model relies on accepting lowest cost bids subject to concerns about system reliability, taking account of a variety of factors on the system, that is, "recognizing any operational limits of generation and transmission facilities."281 The carbon adder would directly change the order in which resources are "dispatched" (come on line) to serve customers, as electricity from some power plants would cost more than it had before. Rates would be directly and significantly impacted, without any intervention by a third party.

\section{B. Addressing Potential Preemption of State Laws}

A set of issues related to deciding whether FERC has impermissibly intruded in an area where it has no authority involve whether FERC's actions preempt state laws impacting wholesale market operations, which is a subject of considerable contention. ${ }^{282}$ In a modern

277 Elec. Power Supply Ass'n, 136 S. Ct. at 775.

278 Wellinghoff \& Morenoff, supra note 50, at 401.

279 Elec. Power Supply Ass'n, 136 S. Ct. at 775; Eisen, Who Regulates The Smart Grid?, supra note 3, at 91; Pierce, Demand Response, supra note 4, at 104.

280 Hammond \& Spence, supra note 8, at 155; see also FERC, SECURITY CONSTRAINED EConomic Dispatch: Definition, Practices, Issues and Recommendations 5 (2006), available at http://www.ferc.gov/industries/electric/indusact/joint-boards/final-cong-rpt.pdf [hereinafter SECURITY CONSTRAINED ECONOMIC DISPATCH].

281 FERC, SECURITy CONSTRAined ECONOMIC DisPatCh, supra note 280, at 10 (citing EPAct 2005 \& 1234).

282 Emily Hammond, Energy Law's Jurisdictional Boundaries: A Call for Course Correction, GEO. WASH. L. REv. DOCKET (Oct. 2014), http://www.gwlr.org/oneok-v-learjet/. 
interconnected electricity network, state laws and policies may influence wholesale market rates. The wholesale markets are interconnected to the retail markets, and courts have recognized this relationship numerous times. The relationship to retail markets does not preclude FERC from acting, as FERC's jurisdiction over wholesale market practices holds even when its actions impact retail customers. ${ }^{283}$

The reverse is not true. In the FPA, "Congress meant to draw a bright line easily ascertained, between state and federal jurisdiction. This was done in the [FPA] by making [FERC] jurisdiction plenary and extending it to all wholesale sales in interstate commerce except those which Congress has made explicitly subject to regulation by the States." 284 As a result, states are barred from regulating matters within FERC's exclusive jurisdiction, ${ }^{285}$ and the Supreme Court has rejected the proposition that the "scope of [FERC's] jurisdiction ... is to be determined by a case-by-case analysis of the impact of state regulation upon the national interest." 286 States have no authority over the wholesale markets. They have jurisdiction over retail sales, but the FPA gives them no jurisdiction correlating to that of section 206 that would give them a say over matters directly affecting the wholesale markets, even if those activities relate to retail rates. ${ }^{287}$ Therefore, a

283 See, e.g., Fed. Power Comm'n v. Conway Corp., 426 U.S. 271, 276-80 (1976) (holding that FERC cannot refuse to consider retail rates in setting just and reasonable wholesale rates). As Justice Scalia recognized in discussing the similar language of section $1(\mathrm{~b})$ of the NGA, FERC may regulate wholesale sales "with an eye toward blunting the sales' anticompetitive effects in the retail market - even though retail prices are controlled by the States." ONEOK, Inc. v. Learjet, Inc., 135 S. Ct. 1591, 1605 (2015) (citing Conway, 426 U.S. at 276-80) (Scalia, J., dissenting).

While the ONEOK decision rejected FERC's authority over manipulation of the natural gas market and allowed state antitrust laws to govern the traders' conduct, it does not detract from FERC's overall ability to regulate wholesale market operations under the practices affecting rates language. The conduct in ONEOK directly involved non-jurisdictional retail markets as well as FERC-jurisdictional wholesale markets, and the state laws "aimed at" general business conduct rather than the markets themselves. Hammond, supra note 282.

284 FPC v. S. Cal. Edison Co., 376 U.S. 205, 215-16 (1964) (internal quotation marks omitted).

285 Schneidewind v. ANR Pipeline Co., 485 U.S. 293, 308 (1988); N. Natural Gas Co. v. State Corp. Comm'n, 372 U.S. 84, 91 (1963) (citation omitted); Pub. Utils. Comm'n v. FERC, 900 F.2d 269, 274 n.2 (D.C. Cir. 1990).

286 Nantahala Power \& Light Co. v. Thornburg, 476 U.S. 953, 966 (1986) (quoting S. Cal. Edison Co., 376 U.S. at 215) (internal quotation marks omitted).

287 Brief for Delaware Division of the Public Advocate et al., in Support of Petition for Certiorari at 18-19, FERC v. Elec. Power Supply Ass'n, 136 S. Ct. 760 (2016) (No. 14-840). 
state cannot directly regulate the wholesale market, for example, by setting its own capacity market price. Thus, we should think of the standard above as providing regulatory space for FERC to do what it must to make the markets work properly, not simply preventing FERC overreach. If FERC could not oversee mechanisms that form the core of the wholesale markets, it would create the kind of regulatory gap that Congress sought to correct when it adopted the FPA in 1935. This interpretation of the FPA closes the Attleboro gap by ensuring that FERC regulates when states cannot. ${ }^{288}$ As the Court recognized in FERC v. EPSA, to do otherwise would leave certain activities completely unregulated; the FPA was designed expressly to avoid creating such regulatory "vacuums." 289

Questions remain, however, whether state laws that have independent justifications but also impact the wholesale markets should stand. Order 745 did not involve preemption, as its opponents took issue with FERC's policy choice, not with its conflict, real or imagined, with any settled state law. ${ }^{290}$ In other cases, it has been difficult to summarize modern preemption analysis, and the judicial decisions are murky, but solicitude for state interests has emerged as an important theme finding a balance between federal and state interests rather than assigning exclusive spheres of regulatory authority.

In recent years, the issue of preemption relating to the electric grid has arisen in several high-profile cases. The conflict with state law has not been found to be express, but implied. The Supreme Court has found preemption implied in several different scenarios.291 "Field preemption" occurs when Congress, without expressly declaring that state laws are preempted, nevertheless legislates so comprehensively as to occupy the entire field of an issue. A second form of implied preemption is "conflict" preemption, which, under current Supreme Court precedent, occurs either when it is impossible for someone to comply with both state and federal laws, or when the purposes and objectives of federal law would be thwarted by state law. ${ }^{292}$ These two scenarios are commonly known as "impossibility" preemption and

288 New York v. FERC, 535 U.S. 1, 6 (2002).

289 Elec. Power Supply Ass'n, 136 S. Ct. at 780.

290 Amicus Curiae Brief of Energy Law Scholars in Support of Petitioners at 15-16, FERC v. Elec. Power Supply Ass'n, 136 S. Ct. 760 (2016) (No. 14-840) [hereinafter Amicus Brief of Energy Law Scholars].

291 Jim Rossi \& Thomas Hutton, Federal Preemption and Clean Energy Floors, 91 N.C. L. Rev. 1285, 1300 (2013) (quoting La. Pub. Serv. Comm'n v. FCC, 476 U.S. 355, 368-69 (1986)).

292 Id. 
"purposes and objectives" (or "obstacle") preemption. The analysis of obstacle preemption requires identification of the purposes and objectives of the federal statute, and a determination of the extent to which the state statute stands as an obstacle, if at all, to the accomplishment of these purposes and objectives. 293

There is a robust body of law on whether implied preemption is constitutional or whether it should be applied in specific cases. ${ }^{294}$ The analysis here takes current forms of implied preemption as a given. Consider the type of law involved in the cases the Court has now taken for argument after FERC $v$. EPSA: a state law that grants financial incentives to prompt construction of new electric generating plants. 295 The state's interests may include promoting development of electricity generation in the state, and a diverse generation mix, 296 among other goals. However, the state's payment would yield revenue to the power plant developer over and above the amount of capacity market payments, and would therefore conflict with the ISO/RTO's scheme of providing a specific incentive through capacity payments. Field preemption analysis was central to the decisions in the cases involving these state laws (from New Jersey and Maryland). ${ }^{297}$ The Third and Fourth Circuits, respectively, overturned these state laws as

293 Geier v. Am. Honda Motor Co., 529 U.S. 861, 873 (2000) (quoting Hines v. Davidowitz, 312 U.S. 52, 67 (1941)).

294 See, e.g., Steven Gardbaum, Congress's Power to Preempt the States, 33 PePp. L. ReV. 39 (2005); Robert L. Glicksman, Nothing Is Real: Protecting the Regulatory Void Through Federal Preemption by Inaction, 26 VA. EnVTL. L.J. 5 (2008); Caleb Nelson, Preemption, 86 VA. L. REV. 225 (2000). For an analysis calling for more state control over energy initiatives and less preemption, see Daniel A. Lyons, Federalism and the Rise of Renewable Energy: Preserving State and Local Voices in the Green Energy Revolution, 64 CASE W. L. REV. 1619 (2014).

295 The New Jersey law was An Act Establishing a Long-Term Capacity Agreement Pilot Program to Promote Construction of Qualified Electric Generation Facilities, Amending and Supplementing P.L.1999, c.23, 2011 N.J. Sess. Law Serv. Ch. 9 (West 2016). It established a "contract for differences" ("CFD") method for providing incentives for new generation. Under the CFD, a winning bidder would be paid (or required to pay) based on the difference between its bid prices for energy and capacity (as reflected in the CFD) and PJM's corresponding price for capacity. The CFD assured that the winning bidder will always be paid the greater of (1) the PJM price or (2) the bidder's winning bid price. 2011 N.J. Sess. Law Serv. Ch. 9 §§ 3(b), 3(c)(4) (West 2016).

296 Hammond \& Spence, supra note 8, at $157 \&$ n.79 (citing statutes from Delaware, Florida, and New York directing state regulators to consider fuel diversity in determining the need for new power plant capacity).

297 See, e.g., PPL Energyplus, LLC v. Solomon, 766 F.3d 241 (3d Cir. 2014), pet'n for cert. filed Dec. 10, 2014; PPL Energyplus, LLC v. Nazarian, 753 F.3d 467 (4th Cir. 2014), cert. granted Oct. 19, 2015. 
impermissible intrusions on FERC's authority to set capacity market prices because they distorted wholesale market rates. In these cases, FERC was held to have occupied the entire field of wholesale market regulation. In October 2015, the Supreme Court granted certiorari in the Maryland cases to review these holdings on the preemption issue. ${ }^{298}$

Given FERC v. EPSA's discussion of the interconnected nature of the electric grid, in which actors pursue initiatives concurrently, scholars have argued that conflict preemption is more appropriate than field preemption for deciding whether FERC's actions preempt state laws. ${ }^{299}$ If FERC's policies for the wholesale market threaten to interfere with historical state authority, the proper way to address this would be in a case-by-case preemption challenge. ${ }^{300}$ By contrast, field preemption analysis leaves no role for the states when FERC takes actions involving the wholesale markets. That is incompatible with the central feature of the directness standard discussed in this Part: FERC has expansive - but not unlimited - authority over matters relating to the wholesale markets. When state law does not interfere with FERC's actions, it should stand.

The touchstone for conflict preemption analysis is congressional intent. Unfortunately, this is both indeterminate in most situations, and difficult (if not impossible) to apply here, given the lack of congressional explication on "practices affecting rates" in the enactment of the FPA. Thus, the standard and factors developed above can provide useful insights about the extent of FERC's authority in a given case, and the extent to which state laws conflict with FERC's actions.

Based on the four factors above, a conflict preemption analysis might well reach the same result with respect to the Maryland laws as the Third and Fourth Circuits did using a field preemption analysis. It would be consistent with the central aim of the "directness" standard: confirming the balance between federal and state authority. An interpretation of the FPA that allocates jurisdiction in this setting must manage the uncertainties in going forward in this complex industry landscape, and accommodate the relative interests of FERC and the states. In this interstate context, "effective regulation" no longer requires rigid adherence to the notion of distinct spheres of jurisdiction, but making the dividing line effective. Where specific conflicts do exist, the challenge is to preserve a state regulatory role,

\footnotetext{
298 Nazarian, 753 F.3d at 467.

299 Rossi \& Hutton, supra note 291, at 1302-03.

300 Amicus Brief of Energy Law Scholars, supra note 290, at 15; Jim Rossi, Lowering the Filed Tariff Shield: Judicial Enforcement for a Deregulatory Era, 56 VAND. L. REV. $1591,1642-46$ (2003).
} 
for example, the states' historical mandate to assess whether specific purchases of power by utilities are prudent. ${ }^{301}$ That can be an important function of the standard described here. There would still be a robust regulatory role for the states; as the Supreme Court has stated recently, "no one could claim that [this] regulation... forecloses every other form of state regulation . . .."302

\section{CONCLUSION}

The wholesale electricity markets are a work in progress. They are an ongoing experiment primarily aimed at delivering low-cost electricity to consumers - and a recent one at that - that does not capture all values such as internalizing environmental externalities. There is much untapped potential for FERC to act within its current statutory authority to change the structure of these markets. After FERC v. EPSA, there are many creative ways that FERC can act, and there are many ways that states can act, some of which would influence the markets. ${ }^{303}$ As the Court recognized, demand response participation in wholesale markets is the epitome of this spirit of experimentation, as it seeks to revamp the markets to introduce a wholly new resource (demand reductions).

Widely held views of the FPA's regulatory scheme believe it to be outmoded as the electric power sector continues to evolve. However, this Article concludes that after FERC v. EPSA, the New Deal-era FPA, designed to rein in monopolists, has continuing relevance in allocating jurisdiction between states and FERC in a modern market-based context. The historical analysis in this Article does not propose a particular type of experimentation, or a particular suite of actions for FERC to use the wholesale markets to address climate change or stimulate innovation. Nor, for that matter, does it attempt to resolve long-standing policy differences between different levels of government. Instead, it attempts to remove more of the uncertainty about what FERC can do, and the limits of a statute that seems a product of a bygone era.

Old statutes, as Jody Freeman and David Spence have cogently argued, can apply to new problems. ${ }^{304}$ So it is here. The Court has now found that FERC's authority over ISO/RTOs and their wholesale

\footnotetext{
301 Nantahala Power \& Light Co. v. Thornburg, 476 U.S. 953, 972 (1986).

302 ONEOK, Inc. v. Learjet, Inc., 135 S. Ct. 1591, 1600 (2015).

303 Hammond \& Spence, supra note 8, at 194-95.

304 Jody Freeman \& David B. Spence, Old Statutes, New Problems, 163 U. PA. L. ReV. 1 (2014).
} 
markets gives it significant powers to make sweeping changes in the markets. The standard enunciated here, based on well over 100 years of precedent, attempts to lessen the dissonance among levels of government. It outlines FERC's broad authority - broader than some would envision - but also provides limits on that authority to guide policymakers at every level of government. 